\title{
Ruminal fermentation, kinetics, and total-tract digestibility of lactating dairy cows fed distillers dried grains with solubles in low- and high-forage diets
}

\author{
Sanjeewa D. Ranathunga, ${ }^{1 *}$ Kenneth F. Kalscheur, ${ }^{1,2} \dagger \ddagger$ and Kevin J. Herrick ${ }^{1} \S$ \\ ${ }^{1}$ Dairy and Food Science Department, South Dakota State University, Brookings 57007 \\ ${ }^{2}$ US Dairy Forage Research Center, USDA-Agricultural Research Service, Madison, WI 53706
}

\section{ABSTRACT}

The objective of this study was to investigate the effects of concentrations of forages and corn distillers dried grains with solubles (DDGS) on ruminal fermentation, ruminal kinetics, and total-tract digestibility of nutrients in lactating dairy cows. Four lactating Holstein cows with ruminal cannulas were assigned to a $4 \times 4$ Latin square in a $2 \times 2$ factorial arrangement of treatments. Diets were formulated to contain low forage $[\mathrm{LF} ; 17 \%$ forage neutral detergent fiber (NDF)] or high forage (HF; $24.5 \%$ forage NDF) and DDGS at 0 or $18 \%$ (0DG or $18 \mathrm{DG}$ ) of diet dry matter (DM). Intake of DM was not affected by the diets. Daily mean ruminal $\mathrm{pH}$ was affected by forage $\mathrm{NDF} \times \mathrm{DDGS}$ interactions, as the lowest ruminal $\mathrm{pH}$ was observed among cows fed LF18DG (6.02). Apparent total-tract digestibility for DM, organic matter, crude protein, NDF, acid detergent fiber, and starch was not affected by diets. Cows fed LF diets had a greater total volatile fatty acid concentration compared with cows fed HF (122 vs. $116 \mathrm{mM}$ ). Molar proportions of acetate were greater for HF compared with that of LF diets (62.6 vs. $57.5 \mathrm{mmol} / 100 \mathrm{mmol}$ ) and greater for 0DG diet compared with that of $18 \mathrm{DG}$ diets $(61.3 \mathrm{vs} .58 .7 \mathrm{mmol} / 100$ $\mathrm{mmol}$ ) diets. The molar proportion of propionate was affected by forage $\times$ DDGS interaction as the greatest propionate molar proportion was observed with cows fed LF18DG diet $(27.7 \mathrm{mmol} / 100 \mathrm{mmol})$. Also, molar proportion of butyrate was affected by forage $\times$ DDGS interaction, as the greatest butyrate molar proportion was observed in cows fed HF18DG diet $(13.5 \mathrm{mmol} / 100$ $\mathrm{mmol})$. Average fractional dilution rate for all diets was

Received September 29, 2018.

Accepted April 27, 2019.

* Current address: Kemin Europa, Animal Nutrition and HealthEMENA, Toekomstlaan 42, Herentals 2200, Belgium.

†Corresponding author: kenneth.kalscheur@ars.usda.gov

$\ddagger$ Current address: US Dairy Forage Research Center, USDA-ARS, 1925 Linden Drive, Madison, WI 53706.

$\S$ Current address: POET Nutrition, 4506 N. Lewis Ave., Sioux Falls, SD 57110 .
$11.9 \% / \mathrm{h}$ and was not affected by diets. Fractional passage rate of the solid phase was greater for HF than for LF (4.40 vs. $3.76 \% / \mathrm{h}$ ). The ruminal retention time of solid phase was greater for LF compared with HF diets ( 27.3 vs. 23.3 h). Fractional passage rate of DDGS was affected by forage $\times$ DG interaction, as the highest fractional passage rate of DDGS was observed with cows fed HF18DG diet $(7.72 \% / \mathrm{h})$. Our results demonstrated that concentrations of forage, DDGS, and their interaction influence ruminal degradation and kinetics of diets fed. Diets formulated at $17 \%$ forage NDF at $17 \%$ (DM basis) can decrease milk fat concentration compared with diets formulated at $25 \%$ forage NDF. Additionally, feeding DDGS at 18\% DM basis to lactating dairy cows did not affect milk fat concentration or yield.

Key words: distillers dried grains with solubles, forage, rumen kinetics, metabolism

\section{INTRODUCTION}

Distillers dried grains with solubles (DDGS), a co-product of the ethanol industry, has been fed as a protein source (Owen and Larson, 1991; Powers et al., 1995; Kleinschmit et al., 2006) in diets of lactating dairy cows. It has also been evaluated as a non-forage fiber source in the diets of lactating dairy cows (Ranathunga et al., 2010, 2018). Several authors have investigated the optimal use of DDGS in lactating dairy cow diets. Schingoethe et al. (2009) recommended that DDGS could be incorporated at $20 \% \mathrm{DM}$ basis in lactating dairy cow diets. More recent research from Testroet et al. (2018) showed no differences in performance when feeding a reduced-fat DDGS at $19.5 \%$ of diet dry matter. However, there are instances where feeding high-fat DDGS from 20 to $30 \%$ on DM basis to lactating dairy cows caused decreased milk fat concentration (Abdelqader et al., 2009; Hippen et al., 2010). Although multifactorial, dietary factors such as inadequate effective fiber and a greater concentration of unsaturated fatty acids could lead to milk fat depression (MFD; Lock, 2010).

A few studies have previously investigated ruminal fermentation characteristics and total-tract digestibil- 
ity of lactating dairy cows fed DDGS (Kelzer et al., 2009; Zhang et al., 2010; Benchaar et al., 2013). However, no published data on ruminal degradation and passage rates of DDGS exists. Therefore, we designed an experiment to investigate the metabolism of DDGS when fed at $18 \%$ of the diet (on a DM basis) with low and high forage concentrations. We hypothesized that degradation of DDGS in the rumen would be different and would not cause decreased milk fat concentration when 18\% DDGS (on a DM basis) was included in diets formulated with high forage concentration compared with diets with low forage concentration. The primary objective of this study was to investigate the effects of including DDGS with low- or high-forage diets on ruminal fermentation, ruminal kinetics, and total-tract digestibility in lactating dairy cows.

\section{MATERIALS AND METHODS}

\section{Animals, Diets, and Experimental Design}

The study was conducted at the Dairy Research and Training Facility at South Dakota State University, Brookings. All procedures involving animals were approved by the South Dakota Institutional Animal Care and Use Committee. Four multiparous cannulated Holstein cows (initial DIM: $179 \pm 56$; initial BW: $722 \pm$ $36 \mathrm{~kg}$ ) were assigned randomly to a $4 \times 4$ Latin square design balanced for carryover effects in a $2 \times 2$ factorial arrangement of treatments with 4 -wk periods. The first $2 \mathrm{wk}$ were used for diet adaptation and the last $2 \mathrm{wk}$ for sampling and data collection. Diets were formulated to contain low forage [LF; $17 \%$ forage neutral detergent fiber (NDF)] or high forage ( $\mathbf{H F} ; 24.5 \%$ forage NDF) and DDGS at 0 or $18 \%$ (0DG or 18DG) of diet DM (Table 1). The DDGS (Glacial Lakes Energy LLC, Watertown, SD) was purchased as a single shipment, to ensure similar composition throughout the experiment. The inclusion of DDGS in 18DG diets resulted in the partial removal of ground corn and total removal of expeller soybean meal and extruded soybeans compared with 0DG diets. A source of rumen inert fat (Energy Booster 100, Milk Specialties Global, Eden Prairie, $\mathrm{MN}$ ) was added to all diets to increase dietary ether extract (EE) concentration. The reference values available in the NRC (2001) were used as the estimates of RDP and RUP, and intestinal values for the feed ingredients. All diets were formulated (NRC, 2001) to be similar in CP (18\%), RDP (10.1\%), and RUP (7.9\%) concentrations on a DM basis.

Forages were premixed in a vertical mixer and blended with concentrates in a Calan Data Ranger (American Calan, Northwood, NH) to mix diets as TMR. Cows were housed in a free-stall barn and fed once daily (0800 h) using Calan Broadbent individual animal feeders ( 1 cow assigned per feeder). Cows were trained for 2 weeks to use the feeding system before initiation of the experiment. Amounts of feed offered were adjusted to allow for ad libitum intake and 5 to $10 \%$ refusal. Dry matter intake was measured individually using data on daily feed offered and refused.

\section{Markers for Ruminal Flow and Apparent Total-tract Digestibility}

Ytterbium-Labeled Corn Silage. Solid passage rates were determined when the experimental diets were fed using Yb. Ytterbium-labeled corn silage was prepared according to the procedure of Varga and Prigge (1982), with some modifications. Initially, 10 $\mathrm{L}$ of $\mathrm{YbCl}_{3}$ solution was prepared, to contain $40 \mathrm{~g}$ of $\mathrm{Yb} / \mathrm{L}$ by adding $460 \mathrm{~g}$ of $99 \% \mathrm{Yb}_{2} \mathrm{O}_{3}$ [ytterbium(III) oxide, Sigma-Aldrich, St. Louis, MO] and $640 \mathrm{~mL}$ of concentrated $\mathrm{HCl}$ (Sigma-Aldrich) into approximately $400 \mathrm{~mL}$ of distilled water and then further diluting to $10 \mathrm{~L}$ using distilled water. The $10 \mathrm{~L}$ of $\mathrm{YbCl}_{3}$ solution was then diluted to $200 \mathrm{~L}$ using tap water, to contain $2 \mathrm{~g}$ of $\mathrm{Yb} / \mathrm{L}$. Approximately $10 \mathrm{~kg}$ of corn silage on wet matter basis $\left(50 \mathrm{~g}\right.$ of forage sample per $1 \mathrm{~L}$ of $\mathrm{YbCl}_{3}$ solution) was soaked in $200 \mathrm{~L}$ of diluted $\mathrm{YbCl}_{3}$ solution for $48 \mathrm{~h}$, with stirring every $6 \mathrm{~h}$. The corn silage mixture was then strained through 2 layers of cheesecloth, washed 6 times with tap water over a 6 -h period to remove any unbound marker, and allowed to air dry for $24 \mathrm{~h}$. Labeled corn silage samples, with average $\mathrm{Yb}$ concentration of $3.3 \mathrm{mg} / \mathrm{g}$ of $\mathrm{DM}$, were divided into equal doses of approximately $750 \mathrm{~g}$ of corn silage on wet matter basis $(17.4 \% \mathrm{DM})$ with $0.43 \mathrm{~g}$ of bound $\mathrm{Yb}$, and stored at $-20^{\circ} \mathrm{C}$.

Cobalt EDTA. The passage rate of rumen fluid was determined using cobalt EDTA, prepared according to Udén et al. (1980) using cobalt acetate [Cobalt(II) acetate, Sigma-Aldrich]. For each cow, $10 \mathrm{~g}$ of cobalt EDTA was dissolved in $1 \mathrm{~L}$ of tap water.

Erbium-Labeled DDGS. Fractional passage rates of DDGS were determined using erbium-labeled DDGS, prepared according to Ellis and Beever (1984). The DDGS was soaked in a solution containing $80 \mathrm{mg}$ of erbium acetate/g of DDGS [erbium(III) acetate hydrate, Sigma-Aldrich], DM basis, in $7.5 \mathrm{~mL}$ of distilled water for $24 \mathrm{~h}$. Then the solution was soaked in $10 \mathrm{~mL}$ of 0.1 $M$ acetic acid/g of DDGS (Sigma-Aldrich), DM basis, for $6 \mathrm{~h}$, followed by rinsing with distilled water. Labeled DDGS samples were dried at $55^{\circ} \mathrm{C}$ in a forced-air oven (style V-23, Despatch Oven Co., Minneapolis, MN) for $48 \mathrm{~h}$ and divided into equal doses of $90 \mathrm{~g}$ on an as-fed 
Table 1. Ingredients and nutrient composition of experimental $\operatorname{diets}^{1}$

\begin{tabular}{|c|c|c|c|c|}
\hline \multirow[b]{2}{*}{ Item } & \multicolumn{2}{|c|}{ Low forage } & \multicolumn{2}{|c|}{ High forage } \\
\hline & ODG & $18 \mathrm{DG}$ & 0DG & $18 \mathrm{DG}$ \\
\hline \multicolumn{5}{|l|}{ Ingredient ( $\%$ of $\mathrm{DM})$} \\
\hline Corn silage & 32.8 & 32.8 & 48.0 & 48.0 \\
\hline Alfalfa hay & 8.20 & 8.20 & 12.0 & 12.0 \\
\hline Dried ground corn & 27.8 & 21.5 & 13.6 & 7.3 \\
\hline DDGS & 0 & 18.0 & 0 & 18.0 \\
\hline Soybean meal (44\% CP) & 10.1 & 11.6 & 9.80 & 11.7 \\
\hline Expeller soybean meal $^{2}$ & 8.21 & 0 & 8.70 & 0 \\
\hline Extruded soybeans & 5.00 & 0 & 5.00 & 0 \\
\hline Soybean hulls & 5.00 & 5.00 & 0 & 0 \\
\hline Rumen inert fat ${ }^{3}$ & 0.55 & 0.55 & 0.75 & 0.75 \\
\hline Limestone & 1.20 & 1.31 & 1.05 & 1.20 \\
\hline Salt, white & 0.55 & 0.55 & 0.55 & 0.55 \\
\hline Dicalcium phosphate & 0.15 & 0.05 & 0.10 & 0.05 \\
\hline Dairy-micro premix ${ }^{4}$ & 0.35 & 0.35 & 0.35 & 0.35 \\
\hline Vitamin $\mathrm{E}^{5}$ & 0.05 & 0.10 & 0.05 & 0.10 \\
\hline \multicolumn{5}{|c|}{ Nutrient ( $\%$ of DM unless noted) } \\
\hline DM (\% of diet) & 55.6 & 55.5 & 47.6 & 47.7 \\
\hline $\mathrm{OM}$ & 93.3 & 93.4 & 93.0 & 93.1 \\
\hline $\mathrm{CP}$ & 17.9 & 18.2 & 18.0 & 18.3 \\
\hline $\mathrm{NDF}$ & 25.0 & 28.3 & 29.0 & 32.3 \\
\hline Forage NDF & 16.8 & 16.8 & 24.5 & 24.5 \\
\hline $\mathrm{ADF}$ & 12.8 & 13.7 & 15.1 & 15.9 \\
\hline $\mathrm{NFC}^{6}$ & 46.7 & 42.1 & 42.0 & 37.2 \\
\hline Starch & 28.1 & 24.9 & 23.2 & 18.8 \\
\hline Ether extract & 3.62 & 4.80 & 4.11 & 5.35 \\
\hline Ash & 6.73 & 6.56 & 6.96 & 6.95 \\
\hline $\mathrm{Ca}$ & 0.85 & 0.84 & 0.77 & 0.73 \\
\hline $\mathrm{P}$ & 0.34 & 0.37 & 0.33 & 0.38 \\
\hline $\mathrm{Mg}$ & 0.24 & 0.25 & 0.25 & 0.26 \\
\hline $\mathrm{K}$ & 1.26 & 1.17 & 1.37 & 1.32 \\
\hline $\mathrm{S}$ & 0.17 & 0.19 & 0.18 & 0.19 \\
\hline $\mathrm{NE}_{\mathrm{L}}(\mathrm{Mcal} / \mathrm{kg})^{7}$ & 1.61 & 1.61 & 1.61 & 1.62 \\
\hline \multicolumn{5}{|l|}{ Physical characteristics } \\
\hline $\mathrm{WHC}^{8}$ & 3.66 & 3.75 & 3.91 & 4.14 \\
\hline $\mathrm{BD}^{9}$ & 0.35 & 0.34 & 0.32 & 0.30 \\
\hline $\mathrm{X}_{\mathrm{gm}}(\mathrm{mm})^{10}$ & 1.58 & 1.52 & 2.04 & 1.87 \\
\hline $\mathrm{S}_{\mathrm{gm}}(\mathrm{mm})^{11}$ & 1.56 & 1.51 & 2.16 & 2.00 \\
\hline peNDF $^{12^{\prime}}$ & 13.0 & 13.7 & 18.5 & 18.7 \\
\hline
\end{tabular}

${ }^{1}$ Diets provided varying concentrations of forage and distillers dried grains with solubles (DDGS): low forage (LF; $41 \%$ of diet DM) or high forage (HF; $60 \%$ of diet DM) and DDGS at 0 or $18 \%$ of diet DM. $0 \mathrm{DG}=0 \%$ DDGS; $18 D G=18 \%$ DDGS.

${ }^{2}$ SoyPlus (West Central Soy, Ralston, IA).

${ }^{3}$ Energy Booster 100 (Milk Specialties Global, Eden Prairie, MN).

${ }^{4}$ Contained $10 \% \mathrm{Mg} ; 2.6 \% \mathrm{Zn} ; 1.7 \mathrm{mg} / \mathrm{kg}$ of Mn; $4,640 \mathrm{mg} / \mathrm{kg}$ of Fe; 4,712 mg/kg of Cu; $396 \mathrm{mg} / \mathrm{kg}$ of I; 119 $\mathrm{mg} / \mathrm{kg}$ of Co; $140 \mathrm{mg} / \mathrm{kg}$ of Se; 2,640,000 IU $/ \mathrm{kg}$ of vitamin A; 528,000 IU $/ \mathrm{kg}$ of vitamin $\mathrm{D}_{3} ;$ and $10,560 \mathrm{IU} / \mathrm{kg}$ of vitamin E (Land O'Lakes, St. Paul, MN).

${ }^{5}$ Vitamin $\mathrm{E}=44,000 \mathrm{IU} / \mathrm{kg}$.

${ }^{6} \mathrm{NFC}=100-(\% \mathrm{NDF}+\% \mathrm{CP}+\%$ ether extract $+\%$ ash; NRC, 2001).

${ }^{7}$ Calculated according to NRC (2001) using analyzed feed values.

${ }^{8} \mathrm{WHC}=$ water-holding capacity $(\mathrm{kg}$ of water $/ \mathrm{kg}$ of feed); WHC of corn silage and alfalfa were 5.04 and 6.40 $\mathrm{kg}$ of water $/ \mathrm{kg}$ of feed, respectively.

${ }^{9} \mathrm{BD}=$ bulk density $\left(\mathrm{g} / \mathrm{cm}^{3}\right)$; $\mathrm{BD}$ of corn silage and alfalfa were 0.23 and $0.30 \mathrm{~g} / \mathrm{cm}^{3}$, respectively.

${ }^{10} \mathrm{X}_{\mathrm{gm}}=$ geometric mean length, as calculated by ASAE (2001); $\mathrm{X}_{\mathrm{gm}}$ of corn silage and alfalfa fed in the study were 4.21 and $1.82 \mathrm{~mm}$, respectively.

${ }^{11} \mathrm{~S}_{\mathrm{gm}}=$ standard deviation of the geometric mean, as calculated by ASAE (2001); $\mathrm{S}_{\mathrm{gm}}$ of corn silage and alfalfa fed in the study were 3.79 and $1.88 \mathrm{~mm}$, respectively.

${ }^{12}$ peNDF $=$ pef $\times$ NDF content of the sample; pef $=$ physical effectiveness factor (the proportion of particles retained on 1.18-mm screen); peNDF of corn silage and alfalfa fed in the study were 37.1 and 25.4, respectively. 
basis, with $0.5 \mathrm{~g}$ of bound Er (average Er concentration of $5.6 \mathrm{mg} / \mathrm{g}$ of $\mathrm{DM})$.

Labeled corn silage (750 g on wet matter basis), cobalt EDTA (10 g of cobalt EDTA dissolved in $1 \mathrm{~L}$ of tap water), and labeled DDGS (90 g on an as-fed basis) were introduced as a single dose via rumen cannula and mixed thoroughly with ruminal contents just before feeding at $0900 \mathrm{~h}$ on $\mathrm{d} 26$ of each period.

Titanium Dioxide. Total-tract digestibility of DM, $\mathrm{NDF}, \mathrm{ADF}, \mathrm{CP}$, starch, and EE was estimated using $\mathrm{TiO}_{2}$. Gelatin capsules containing $\mathrm{TiO}_{2}$ were placed approximately $30 \mathrm{~cm}$ into the dorsal area of the rumen via cannula of each cow at 0900 and 2100 , at a rate of 20 $\mathrm{g} / \mathrm{d}$, from d 19 to 28 of each period.

\section{Sample Collection}

Samples of corn silage, alfalfa, concentrate mixes, and TMR were collected for 3 consecutive days at the beginning of wk 3 and 4 of each period and stored at $-20^{\circ} \mathrm{C}$ until analyzed.

Ruminal contents were collected on d 26 of each period from 3 locations (the dorsal, ventral, and caudal areas in the rumen) at $0,1,2,4,6,8,12,16,24,48$, and $72 \mathrm{~h}$ after feeding. Contents were mixed by hand and filtered through 4 layers of cheesecloth to separate ruminal solids and rumen fluids. Ruminal solids were used for $\mathrm{Yb}$ and Er analysis, whereas rumen fluid samples were used for measurements of ruminal $\mathrm{pH}$, VFA, $\mathrm{NH}_{3}-\mathrm{N}$, and Co concentrations. The $\mathrm{pH}$ of ruminal fluid was measured immediately, using a hand-held digital $\mathrm{pH}$ meter (Waterproof $\mathrm{pH}$ Tester 30, Oaktron Instruments, Vernon Hills, IL). Ten milliliters of rumen fluid was placed in a plastic vial with $200 \mu \mathrm{L}$ of 9.38 $M$ sulfuric acid for $\mathrm{NH}_{3}$ analysis. Another $20 \mathrm{~mL}$ was collected into a plastic vial for VFA analysis and mixed with $4 \mathrm{~mL}$ of $25 \%$ metaphosphoric acid. Approximately $30 \mathrm{~mL}$ of rumen fluid was collected for Co analysis.

Total ruminal contents were evacuated manually through ruminal cannula approximately $4 \mathrm{~h}$ after feeding on the last day of each period. Total ruminal contents were weighed, and representative samples were collected. All ruminal samples were immediately frozen at $-20^{\circ} \mathrm{C}$ until analysis.

A total of 12 fecal grab samples were collected per cow per period, from d 25 to 28 each period. The fecal sampling schedule represented every $2 \mathrm{~h}$ of a 24 -h period, to account for diurnal variation. At each sampling point, approximately $500 \mathrm{~g}$ of feces was collected from each cow. Fecal samples were mixed well, and a representative fecal sample of $100 \mathrm{~g}$ on a wet matter basis from each time point was used to make a composite sample per cow per period. Composited samples were frozen at $-20^{\circ} \mathrm{C}$.

\section{Chemical Analysis of Samples}

Feed samples were composited by period and dried at $55^{\circ} \mathrm{C}$ in a forced-air oven (style V-23, Despatch Oven Co.) for $48 \mathrm{~h}$. All samples were ground through a $2-\mathrm{mm}$ screen using a Wiley mill (model 3; Thomas Scientific, Swedesboro, NJ) and then further ground through a 1-mm screen using an ultracentrifuge mill (Brinkmann Instruments, Westbury, NY). All feed samples were analyzed for DM $\left(105^{\circ} \mathrm{C}\right.$ for $3 \mathrm{~h}$; Shreve et al., 2006). Ash was determined at $450^{\circ} \mathrm{C}$ for $8 \mathrm{~h}$ (AOAC International, 2006). Crude protein was determined using an automated N combustion analyzer (Elementar Analysensysteme GmbH, Hanau, Germany) as described in AOAC International (2006; method 968.06). Concentrations of NDF (Van Soest et al., 1991) and ADF (Robertson and Van Soest, 1981) were determined sequentially, using the Ankom fiber analysis system (Ankom Technology, Macedon, NY). Sodium sulfite and $\alpha$-amylase (Ankom Technology) were added during NDF extraction. The EE was analyzed according to AOAC procedure (method 920.39; AOAC International, 2006) using an Ankom ${ }^{\mathrm{X} 10}$ Extractor (Ankom Technology), with diethyl ether as the solvent. Starch concentration was determined using an enzyme-based (thermostable $\alpha$-amylase and amyloglucosidase) total starch assay (method 996.11, AOAC International, 2002; Total Starch Assay Procedure, Megazyme International Ireland Ltd., Wicklow, Ireland). Composites of corn silage, alfalfa hay, DDGS, and TMR were sent to Dairyland Laboratories Inc. (Arcadia, WI) for mineral analysis $(\mathrm{Ca}$, $\mathrm{P}, \mathrm{K}, \mathrm{Mg}$, and $\mathrm{S}$ ). Minerals were quantified according to AOAC procedures (method 953.01; AOAC International, 2006) using an inductively coupled plasma spectrometer (Thermo Jarrell Ash, Franklin, MA). The chemical composition of diets was calculated based on analysis of individual forages (corn silage and alfalfa) and respective concentrate mixes and proportions of each ingredient in the diet.

Rumen fluid samples were thawed and centrifuged at $30,000 \times g$ for 20 min before analysis. Rumen $\mathrm{NH}_{3^{-}}$ $\mathrm{N}$ concentration was analyzed according to Chaney and Marbach (1962). Ruminal VFA concentration was analyzed using gas chromatography (model 6890, Hewlett Packard, Palo Alto, CA) with a flame-ionization detector. An internal standard, 2-ethylbutyrate, was added to the sample before analysis. The column used for VFA separation was $15 \mathrm{~m}$ in length with an inside diameter of $0.25 \mathrm{~mm}$ (Nukol, 17926-01C, Supelco Inc., Bellefonte, PA). Split ratio of 100:1 in the injector port was at a temperature of $250^{\circ} \mathrm{C}$, with flow rate of $1.3 \mathrm{~mL} / \mathrm{min}$ of helium. Column and detector temperature were maintained at $140^{\circ} \mathrm{C}$ and $250^{\circ} \mathrm{C}$, respectively. 
Ruminal solids samples with rare earth markers ( $\mathrm{Yb}$ and Er) and rumen samples from ruminal evacuation were lyophilized using an FTS Systems Dura-Dry MP floor-model freeze dryer (FTS Systems Inc., Stone Ridge, NY). Samples were then ground to pass through a 2-mm screen (Wiley mill; Thomas Scientific) and a 1-mm screen (ultracentrifuge mill, Brinkmann Instruments), and stored at room temperature until they were analyzed. Rumen samples from ruminal evacuation were analyzed for $\mathrm{DM}, \mathrm{NDF}, \mathrm{ADF}, \mathrm{CP}$, and starch, as described above.

Ruminal solid samples containing $\mathrm{Yb}$ and Er were prepared for analysis by diethylenetriamine pentaacetate (DTPA) extraction method (Karimi et al., 1986), with a few modifications. Briefly, $0.4 \mathrm{~g}$ of sample was weighed into a $59-\mathrm{mL}$ plastic vial (Capitol Vial, Thermo Fisher Scientific, Waltham, MA) and stirred continuously for $2 \mathrm{~h}$ with $20 \mathrm{~mL}$ of $0.1 \mathrm{M}$ diethylenetriaminepentaacetic acid without $\mathrm{KCl}$ in a shaking water bath (model 129, Thermo Fisher Scientific). The sample was filtered through a filter paper (Whatman 41, GE Healthcare, Maidstone, UK), and filtrate was analyzed for Yr and Er using an inductively coupled plasma spectrometer (Thermo Jarrell Ash). Rumen fluid samples collected at $0,1,2,4,6,8,12,16$, and 24 $\mathrm{h}$ after feeding were thawed and centrifuged $(2,000 \times g)$ for $20 \mathrm{~min}$. Then supernatant was filtered through a filter paper (Whatman 41), and filtrate was analyzed for Co using an inductively coupled plasma spectrometer (Thermo Jarrell Ash).

Fecal composites were thawed and lyophilized using a Dura-Dry MP floor-model freeze dryer (FTS Systems Inc.). Then fecal samples were ground to pass through a 2-mm screen (Wiley mill; Thomas Scientific) and a 1-mm screen (ultracentrifuge mill, Brinkmann Instruments). All fecal samples were analyzed for DM, $\mathrm{NDF}, \mathrm{ADF}, \mathrm{CP}$, and starch, as described above. Fecal titanium dioxide concentration was measured according to the procedure of Myers et al. (2004) with a few modifications by Herrick et al. (2012). These analyses were then used to calculate total-tract digestibility of $\mathrm{DM}, \mathrm{OM}, \mathrm{CP}, \mathrm{ADF}$, and NDF for each cow.

\section{Physical Properties of Feed Samples}

Water-holding capacity (WHC) of forages and TMR were measured according to the centrifugation method described by Robertson et al. (1980), with a few modifications. Samples used for measuring WHC were dried and ground as previously described. Briefly, $0.5 \mathrm{~g}$ of sample was accurately weighed into a pre-weighed 50$\mathrm{mL}$ centrifuge tube and soaked for $24 \mathrm{~h}$ in $25 \mathrm{~mL}$ of distilled water. The sample was centrifuged at 6000 $\times g$ for $20 \mathrm{~min}$, and supernatant was discarded. The wet sample was weighed, and WHC was calculated as $\mathrm{kg}$ water $/ \mathrm{kg}$ of sample DM. Bulk density $(\mathrm{g} / \mathrm{mL})$ was determined by filling a 500-mL container using a filling hopper (Seedburo Equipment Co., Des Plaines, IL) and weighing the amount of feed ingredients or TMR needed to fill the container.

\section{Particle Size Distribution and Physically Effective Fiber}

Particle size distribution of individual feed ingredients and TMR was measured using a dry sieving method (Mertens, 1997). Corn silage, alfalfa, and TMR samples composited by period were dried at $55^{\circ} \mathrm{C}$ in a forced-air oven (style V-23, Despatch Oven Co.) for 48 h before sieving. Other individual feed ingredients were not subjected to drying. Approximately $100 \mathrm{~g}$ of each sample was used for sieving. Individual feed ingredients, except corn silage and alfalfa, were sieved through 2.36, 1.70, $1.18,0.85,0.60,0.43,0.30,0.212,0.150,0.106,0.075$, 0.053 , and $0.045-\mathrm{mm}$ screens. Corn silage, alfalfa, and TMR were sieved through 12.7, 9.51, 4.76, 3.35, 2.36, $1.18,0.60$, and $0.075-\mathrm{mm}$ screens of a Rototap shaker (model RX-29, W. S. Tyler, Mentor, OH; ASAE, 2001). The geometric mean $\left(\mathbf{X}_{\mathrm{gm}}\right)$ and the standard deviation of the geometric mean $\left(\mathbf{S}_{\mathbf{g m}}\right)$ were calculated for both methods according to ASAE (2001).

The physical effectiveness factor (pef) and physically effective NDF (peNDF) were measured using a drysieving method (Mertens, 1997). The pef was determined based on the proportion of DM retained on the 1.18-mm sieve (pef ${ }_{1.18}$ ), and peNDF was calculated as NDF content of the respective individual feed ingredient, TMR or orts, multiplied by pef.

\section{Milk Production and Composition}

Cows were milked 3 times per day at 0600, 1400, and $2100 \mathrm{~h}$, and individual milk yields were recorded at each milking. Milk samples were collected from each milking for 2 consecutive days of wk 3 (d 17 and 18) and 4 (d 24 and 25) of each period. All collected milk samples were sent to Heart of America DHIA Laboratory (Manhattan, KS) for milk composition analysis using AOAC International (2006) approved methods. Milk fat, protein, and lactose were analyzed using mid-infrared spectroscopy (Bentley 2000 Infrared Milk Analyzer, Bentley Instruments, Chaska, MN; AOAC International, 2006). Concentration of MUN was analyzed using chemical methodology based on a modified Berthelot reaction (ChemSpec 150 Analyzer, Bentley Instruments), and SCC were determined using a flow cytometer laser (Somacount 500, Bentley Instruments; AOAC International, 2006). Somatic cell counts were 
converted to SCS, where SCS $=\log _{10}(\mathrm{SCC})$. Energycorrected milk was determined using the following equation (Orth, 1992):

$$
\begin{gathered}
{[0.327 \times \text { milk yield }(\mathrm{kg})]+[12.95 \times \text { fat yield }(\mathrm{kg})]} \\
+[7.2 \times \text { protein yield }(\mathrm{kg})] .
\end{gathered}
$$

\section{Mathematical and Statistical Analyses}

Ruminal fractional passage rates $\left(\mathbf{K}_{\mathbf{p}}\right)$ of solid, liquid, and DDGS were calculated according to Grovum and Williams (1973). Natural logarithms of marker concentrations of $\mathrm{Yb}, \mathrm{Co}$, and Er at different time points were calculated and plotted against time. It was assumed that the slope of the linear portion of the curve represented $K_{p}$ of that fraction. Ruminal retention time of solid, liquid, and DDGS was calculated as the reciprocal of the respective $K_{p}$ :

$$
\begin{gathered}
\text { Ruminal retention time }=1 / \mathrm{K}_{\mathrm{p}} \text { of cobalt, } \\
\text { ytterbium, or erbium. }
\end{gathered}
$$

The area below ruminal $\mathrm{pH} 6.0$ was calculated using Microcal Origin, version 6.0 (Microcal Software Inc., Northampton, MA), and h below $\mathrm{pH} 6.0$ was calculated according to the data on area below ruminal $\mathrm{pH}$ 6.0.

All data were analyzed as period means using MIXED procedure in SAS (version 9.3, SAS Institute Inc., Cary, $\mathrm{NC})$ in a $4 \times 4$ Latin square design. Weekly means of DMI and milk yield from the final 2 wk of each period were used for statistical analysis. Means for milk composition were determined from individual samples taken at each milking twice weekly during wk 3 and 4 . Means for average $\mathrm{pH}$ measures, rumen kinetics, and total-tract digestibility were calculated for each period and used for statistical analysis. The statistical model used for feed intake, milk production and composition, average $\mathrm{pH}$ measures, rumen kinetics, and total-tract digestibility was as follows:

$$
\begin{gathered}
\mathrm{Y}_{\mathrm{ijkl}}=\mu+\text { forage } \mathrm{NDF}_{\mathrm{i}}+\text { DDGS }_{\mathrm{j}} \\
+\left(\text { forage } \mathrm{NDF}_{\mathrm{i}} \times \operatorname{DDGS}_{\mathrm{j}}\right)+\mathrm{P}_{\mathrm{k}}+\mathrm{C}_{\mathrm{l}}+\varepsilon_{\mathrm{ijkl}},
\end{gathered}
$$

where $Y_{i j k l}$ is the dependent variable, $\mu$ is the overall mean, forage $\mathrm{NDF}_{\mathrm{i}}$ is the effect of forage level $\mathrm{i}(\mathrm{i}=1$ to 2), DDGS $\mathrm{D}_{\mathrm{j}}$ is the effect of DDGS $\mathrm{j}$ ( $\mathrm{j}=1$ to 2 ), (forage $\mathrm{NDF}_{\mathrm{i}} \times \mathrm{DDGS}_{\mathrm{j}}$ ) is the effect of the interaction of forage level $\mathrm{i}$ and DDGS level $\mathrm{j}, \mathrm{P}_{\mathrm{k}}$ is the effect of period $\mathrm{k}(\mathrm{k}$ $=1$ to 4$), \mathrm{C}_{\mathrm{l}}$ is the effect of cow $\mathrm{l}(\mathrm{l}=1$ to 4$)$, and $\varepsilon_{\mathrm{ijkl}}$ is the residual error. Cow was used as an experimental unit and was considered as the random variable in the model.
Data on diurnal variation of ruminal $\mathrm{pH}, \mathrm{NH}_{3}-\mathrm{N}$, and VFA concentrations were analyzed using the repeated measures approach, and time was used as the repeated measure. Based on the lowest value according to Akaike's information criterion (Littell et al., 1996), the compound symmetric structure type was selected as the appropriate covariance structure. The statistical model used for repeated measures was as follows:

$$
\begin{gathered}
\mathrm{Y}_{\mathrm{ijklm}}=\mu+\text { forage }_{\mathrm{i}}+\text { DDGS }_{\mathrm{j}}+\left(\text { forage }_{\mathrm{i}} \times \text { DDGS }_{\mathrm{j}}\right) \\
+\mathrm{P}_{\mathrm{k}}+\mathrm{C}_{\mathrm{l}}+\varepsilon_{\mathrm{ijk} \mathrm{l}}+\mathrm{T}_{\mathrm{m}}+\left(\text { forage }_{\mathrm{i}} \times \mathrm{T}_{\mathrm{m}}\right) \\
+\left(\text { DDGS }_{\mathrm{j}} \times \mathrm{T}_{\mathrm{m}}\right)+\left(\text { forage }_{\mathrm{i}} \times \text { DDGS }_{\mathrm{j}} \times \mathrm{T}_{\mathrm{m}}\right)+\omega_{\mathrm{ijkm}},
\end{gathered}
$$

where $Y_{\mathrm{ijklm}}$ is the dependent variable, $\mu$ is the overall mean, forage $e_{i}$ is the effect of forage level $\mathrm{i}$ ( $\mathrm{i}=1$ to 2 ), DDGS $_{j}$ is the effect of DDGS $\mathrm{j}\left(\mathrm{j}=1\right.$ to 2 ), (forage $\mathrm{i}_{\mathrm{i}} \times$ $D_{D G S}$ ) is the effect of the interaction of forage level $i$ and DDGS level $\mathrm{j}, \mathrm{P}_{\mathrm{k}}$ is the effect of period $\mathrm{k}(\mathrm{k}=1$ to 4), $\mathrm{C}_{1}$ is the effect of cow l (l=1 to 4$), \varepsilon_{\mathrm{ijkl}}$ is the whole plot error, $\mathrm{T}_{\mathrm{m}}$ is the effect of time $\mathrm{m}(\mathrm{m}=1$ to 9$)$, for$\operatorname{age}_{\mathrm{i}} \times \mathrm{T}_{\mathrm{m}}$ is the effect of the interaction of forage level $\mathrm{i}$ and time $\mathrm{m}, \mathrm{DDGS}_{\mathrm{j}} \times \mathrm{T}_{\mathrm{m}}$ is the effect of the interaction of DDGS level $\mathrm{j}$ and time $\mathrm{m},\left(\right.$ forage $\left._{\mathrm{i}} \times \mathrm{DDGS}_{\mathrm{j}} \times \mathrm{T}_{\mathrm{m}}\right)$ is the interaction between forage $i$, DDGS $j$, and time $\mathrm{m}$, and $\omega_{\mathrm{ijkm}}$ is the subplot error. Cow was used as an experimental unit and was considered as the random variable in the model.

Least squares means were reported for each variable. Interactions of main effects were declared significant at $P \leq 0.05$, and tendencies for main effects were declared at $0.05<P \leq 0.10$. Mean comparisons using the PDIFF test were performed when there was a significant interaction between the main effects, forage NDF $\times$ DDGS interactions $(P \leq 0.05)$.

\section{RESULTS}

\section{Dietary Treatments}

The ingredient and chemical composition of the diets, concentrate mixes, corn silage, alfalfa hay, DDGS, ground corn, soybean meal, expeller soybean meal, extruded soybeans, and soy hulls are presented in Tables 1 and 2. Data on particle size distribution, pef, peNDF, and physical characteristics of the individual feed ingredients and concentrate mixes are presented in Table 3. The concentrations of $\mathrm{OM}$ and $\mathrm{CP}$, as well as $\mathrm{NE}_{\mathrm{L}}$, were similar across diets, averaging 93.2 and $18.1 \%$, and 1.61 $\mathrm{Mcal} / \mathrm{kg}$, respectively. Forage NDF concentration for $\mathrm{HF}$ and LF diets were 24.5 and $16.8 \%$, respectively. Dietary NDF and ADF concentrations were greater for HF diets than for LF diets by 4.00 and $2.25 \%$ units, respectively. Also, dietary NDF and ADF concentrations 
were greater for $18 \mathrm{DG}$ diets by 3.30 and $0.85 \%$ units, respectively, compared with 0DG diets. Starch concentrations of the diets, LF0DG, LF18DG, HF0DG, and HF18DG, were $28.1,24.9,23.2$, and $18.8 \%$, respectively. Diets were formulated to have similar EE concentration of $4.30 \%$ across the diets. However, chemical analysis of diets fed to cows showed that EE concentration of the diets were not similar across the diets, possibly attributable to the differences in the EE value used for diet formulation and value from the actual analysis of DDGS after the study.

\section{Nutrient Intakes}

Nutrient intakes of cows fed experimental diets are presented in Table 4 . Diet did not affect $(P>0.10)$ intake of DM $(23.9 \mathrm{~kg} / \mathrm{d})$ or CP $(4.32 \mathrm{~kg} / \mathrm{d})$. Interactions of main effects were observed for intake of forage NDF $(P=0.05)$ and $\mathrm{EE}(P=0.01)$. As expected, total $\mathrm{NDF}$ intake was greater for HF diets than for LF diets $(7.2$ vs. $6.4 \mathrm{~kg} / \mathrm{d} ; P=0.002)$. Cows fed the $18 \mathrm{DG}$ diets also had greater NDF intake compared with cows fed the $0 D G$ diets $(7.1$ vs. $6.5 \mathrm{~kg} / \mathrm{d} ; P=0.002)$. The ADF intake also was greater for HF diets than for LF diets $(3.7$ vs. $3.2 \mathrm{~kg} / \mathrm{d} ; P=0.001)$. Starch intake was greater for LF diets than for HF diets (6.40 vs. $4.95 \mathrm{~kg} / \mathrm{d} ; P<$ 0.001 ), as well as for 0DG diets compared with $18 \mathrm{DG}$ $\operatorname{diets}(6.25$ vs. $5.10 \mathrm{~kg} / \mathrm{d} ; P<0.001)$.

\section{Ruminal $\mathrm{pH}$ and Fermentation}

Data on ruminal $\mathrm{pH}$ and fermentation characteristics are presented in Table 5 . There was no forage $\times$ DDGS $\times$ time interaction for ruminal $\mathrm{pH}(P=0.41$; data not shown). The maximum $\mathrm{pH}$ was observed with cows fed HF diets (6.87 vs. 6.66 for LF diets; $P=0.04$ ). Analysis revealed a tendency to have greater $(P=0.09)$ variance of $\mathrm{pH}$ associated with LF diets compared with HF diets. Ruminal $\mathrm{pH}$ was below 6 for more than $16 \mathrm{~h}$ when cows were fed with LF diets, whereas it was around $6 \mathrm{~h}$ when cows were fed with HF diets $(P<0.01)$.

We found no forage $\times$ DDGS $\times$ time interaction for total VFA concentration ( $P=0.45$; data not shown). Cows fed the HF diets had less total VFA (122 vs. $116 \mathrm{~m} M ; P=0.03)$ than did cows fed LF diets. Molar proportions of acetate were lower for LF compared with HF diets (57.5 vs. $62.6 \mathrm{mmol} / 100 \mathrm{mmol} ; P<0.001$ ). Molar proportion of propionate and butyrate were affected by the interaction of the main effects $(P<0.001)$. Molar proportion of isobutyrate was greater for cows fed HF diets than for those fed LF diets (0.96 vs. 0.88 $\mathrm{mmol} / 100 \mathrm{mmol} ; P<0.001)$. There was an interaction for the main dietary effects for the valerate molar proportion $(P=0.02)$. Including greater amounts of
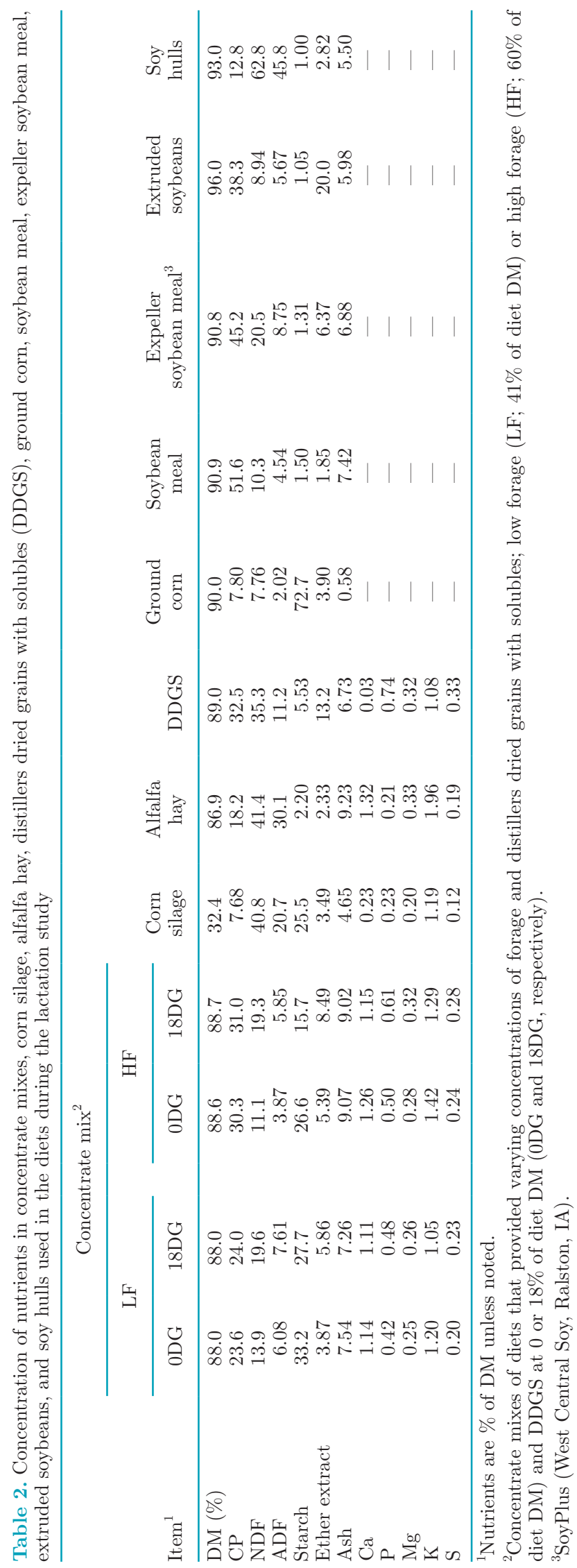
RUMINAL FERMENTATION OF DISTILLERS GRAINS WITH FORAGE FIBER

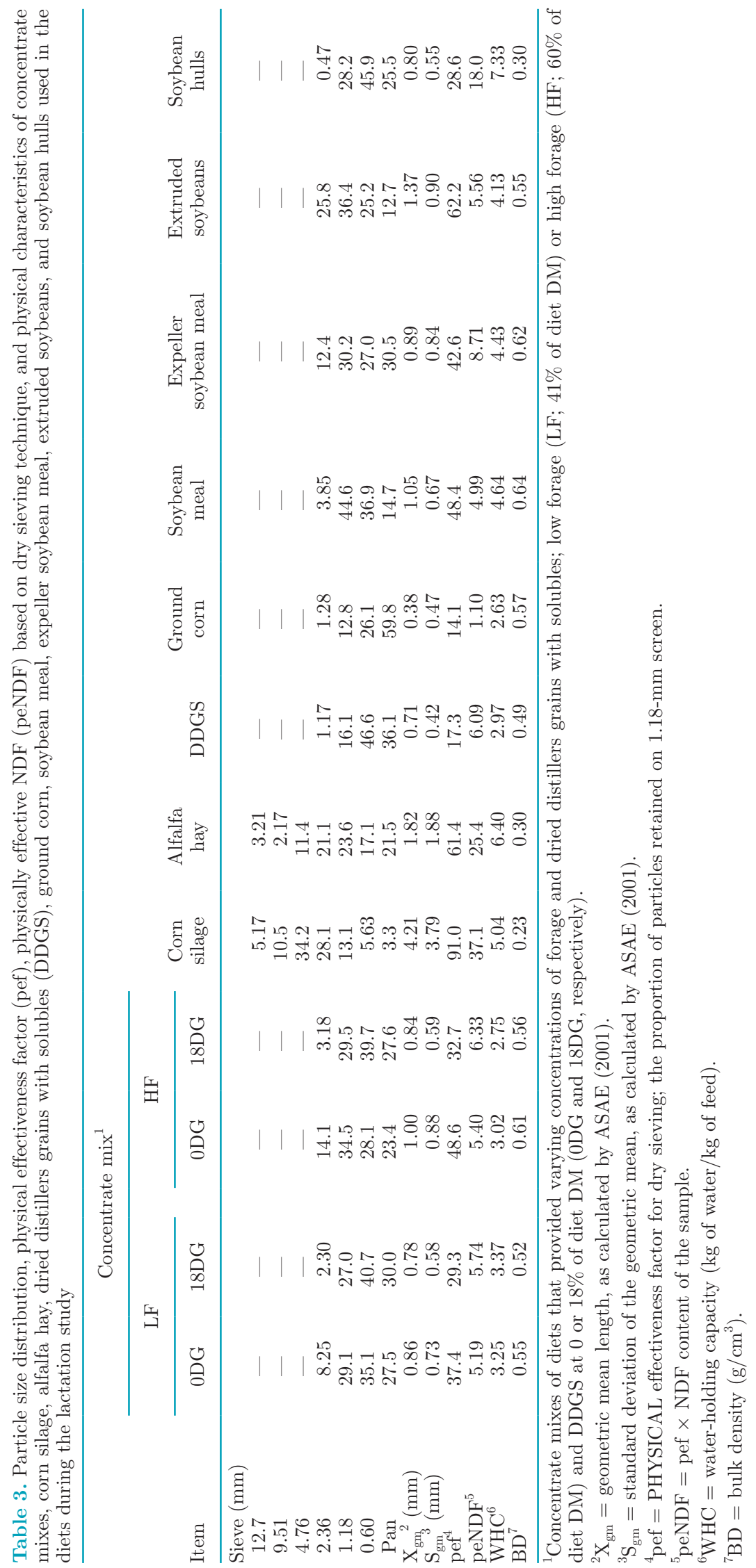


Table 4. Nutrient intakes of dairy cows fed experimental diets ${ }^{1}$

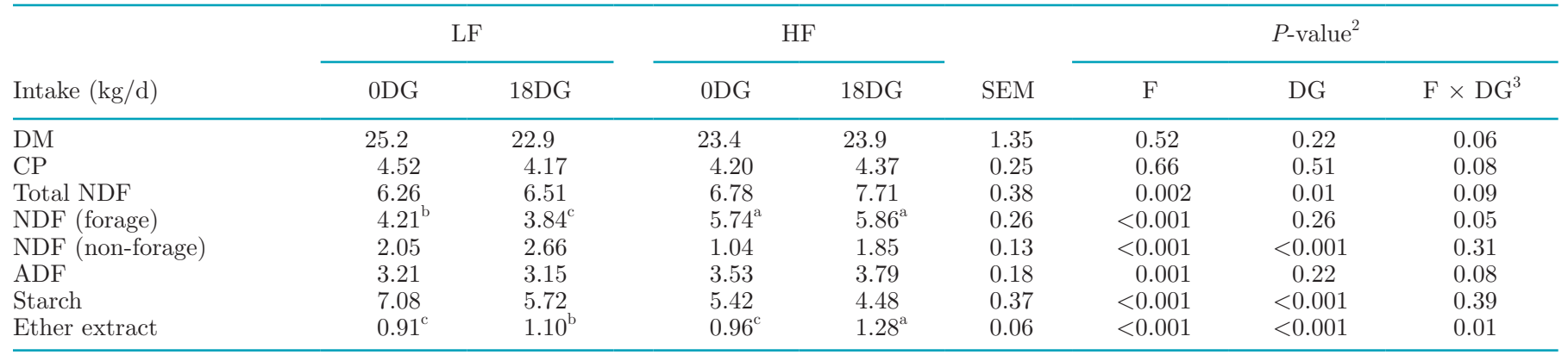

${ }^{a-c}$ Treatment means in same row followed by different superscript letters differ significantly $(P<0.05)$.

${ }^{1}$ Diets provided varying concentrations of forage and distillers dried grains with solubles (DDGS); low forage (LF; $41 \%$ of diet DM) or high forage (HF; $60 \%$ of diet DM) and DDGS at 0 or $18 \%$ of diet DM. $0 \mathrm{DG}=0 \%$ DDGS; $18 \mathrm{DG}=18 \%$ DDGS.

${ }^{2} \mathrm{~F}=$ effect of dietary forage NDF concentration; DG $=$ effect of DDGS concentration; $\mathrm{F} \times \mathrm{DG}=$ interaction of dietary forage NDF concentration and DDGS concentration $(P<0.05)$.

${ }^{3}$ PDIFF test was conducted if $P<0.05$ for interactions of main effects.

DDGS resulted in lower proportions of ruminal acetate (57.5 vs. $62.6 \mathrm{mmol} / 100 \mathrm{mmol} ; P<0.001$ ) but did not affect total VFA concentration $(P=0.69)$. The ratio of acetate to propionate was lower for LF (2.29 vs. 3.16; $P<0.001)$ and 18 DG diets $(2.53$ vs. $2.93 ; P<0.001)$ compared with cows fed HF and $0 \mathrm{DG}$ diets, respectively. We also discovered a tendency toward lower $\mathrm{NH}_{3}-\mathrm{N}$ concentration for 0DG diets compared with 18DG diets $(P=0.10)$.

\section{Ruminal Digestion Kinetics}

Data on rumen fill and rumen digestion kinetics are presented in Table 6. Ruminal content was affected by forage $\times$ DDGS interaction on wet matter basis $(P=$ $0.03)$ and DM basis $(P<0.001)$. Cows fed HF diets had greater ruminal content on wet matter basis (91.6 vs. $81.0 \mathrm{~kg} ; P<0.001)$ and DM basis $(13.4$ vs. $12.2 \mathrm{~kg}$; $P<0.001)$ compared with LF diets. Ruminal liquid

Table 5. Ruminal $\mathrm{pH}$, volatile fatty acids (VFA) and ammonia concentrations in dairy cows fed experimental diets ${ }^{1}$

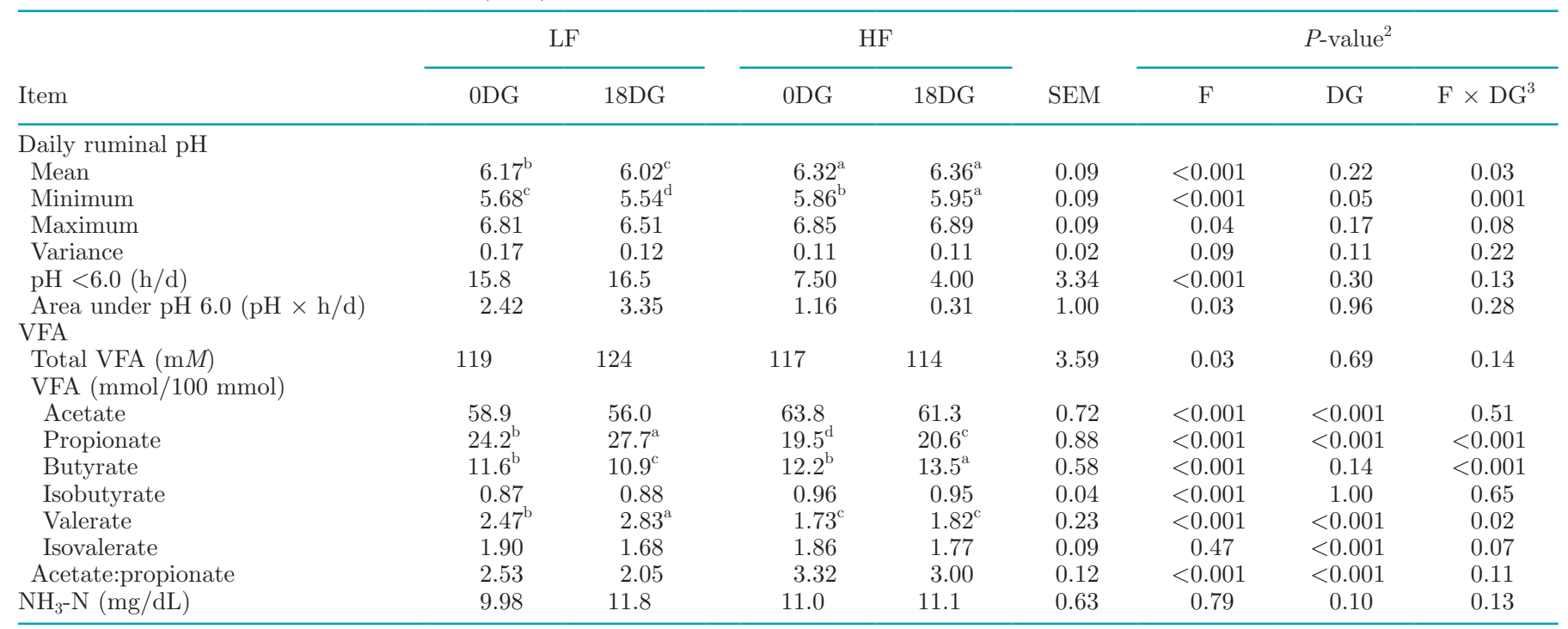

\footnotetext{
${ }^{\mathrm{a}-\mathrm{d}}$ Treatment means in same row followed by different superscript letters differ significantly $(P<0.05)$.
}

${ }^{1}$ Diets provided varying concentrations of forage and distillers dried grains with solubles (DDGS); low forage (LF; $41 \%$ of diet DM) or high forage (HF; $60 \%$ of diet DM) and DDGS at 0 or $18 \%$ of diet DM. $0 \mathrm{DG}=0 \%$ DDGS; $18 \mathrm{DG}=18 \%$ DDGS.

${ }^{2} \mathrm{~F}=$ effect of dietary forage NDF concentration; DG $=$ effect of DDGS concentration; $\mathrm{F} \times \mathrm{DG}=$ interaction of dietary forage NDF concentration and DDGS concentration $(P<0.05)$.

${ }^{3}$ PDIFF test was conducted if $P<0.05$ for interactions of main effects. 
Table 6. Rumen fill and ruminal digestion kinetics of dairy cows fed experimental diets ${ }^{1}$

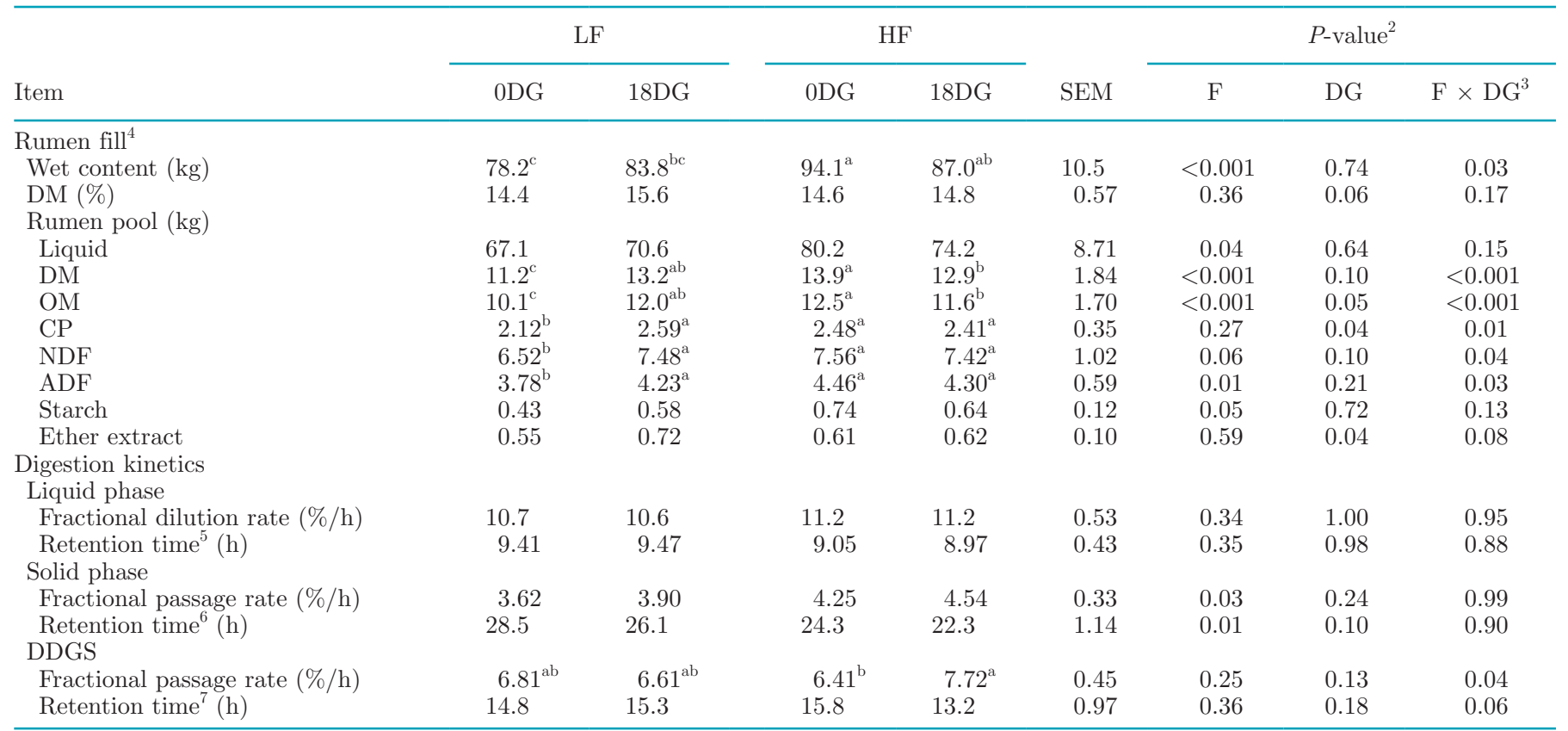

${ }^{\mathrm{a}-\mathrm{c}}$ Treatment means in same row followed by different superscript letters differ significantly $(P<0.05)$.

${ }^{1}$ Diets provided varying concentrations of forage and distillers dried grains with solubles (DDGS); low forage (LF; $41 \%$ of diet DM) or high forage (HF; $60 \%$ of diet DM) and DDGS at 0 or $18 \%$ of diet DM. 0DG $=0 \%$ DDGS; $18 \mathrm{DG}=18 \%$ DDGS.

${ }^{2} \mathrm{~F}=$ effect of dietary forage NDF concentration; DG = effect of DDGS concentration; $\mathrm{F} \times \mathrm{DG}=$ interaction of dietary forage NDF concentration and DDGS concentration $(P<0.05)$.

${ }^{3}$ PDIFF test was conducted if $P<0.05$ for interactions of main effects.

${ }^{4}$ Manual empty.

${ }^{5}$ Ruminal retention time $=1 /$ rate of passage of cobalt.

${ }^{6} \mathrm{Ruminal}$ retention time $=1 /$ rate of passage of ytterbium

${ }^{7}$ Ruminal retention time $=1 /$ rate of passage of erbium.

pools were greater for HF diets compared with LF diets $(77.2$ vs. $68.9 \mathrm{~kg} ; P=0.04)$. Forage $\times$ DDGS interactions displayed effects on ruminal pools of OM $(P<$ $0.001), \mathrm{CP}(P=0.01), \operatorname{NDF}(P=0.04)$, and $\operatorname{ADF}(P=$ $0.03)$. Cows fed HF diets had a greater ruminal starch content than did cows fed LF diets (0.69 vs. $0.51 \mathrm{~kg} / \mathrm{d}$; $P=0.03)$. Cows fed $18 \mathrm{DG}$ had a greater ruminal EE content compared with cows fed LF diets (0.67 vs. 0.58 $\mathrm{kg} / \mathrm{d} ; P=0.04)$.

Average fractional dilution rate and liquid ruminal retention time of diets were $10.9 \% / \mathrm{h}$ and $9.23 \mathrm{~h}$, respectively, and neither was affected by dietary treatments. Fractional passage rate of solid phase based on corn silage was lower (3.76 vs. $4.40 \% / \mathrm{h} ; P=0.03)$ for cows fed LF diets compared with HF diets. However, the ruminal retention time of solid phase was greater $(27.3$ vs. $23.3 \mathrm{~h} ; P=0.01$ ) for $\mathrm{LF}$ diets than for HF diets, whereas it tended to be greater $(26.4$ vs. $24.2 \mathrm{~h} ; P=$ 0.10 ) for $0 \mathrm{DG}$ diets than for $18 \mathrm{DG}$ diets. An interaction of main effects was observed for the fractional passage rate of the labeled DDGS $(P=0.04)$.

\section{Total-Tract Digestibility}

Data on apparent total-tract digestibility and amount of digested nutrients per day are presented in Table 7 . Apparent total-tract digestibility of DM, NDF, ADF, $\mathrm{CP}$, and starch was not affected by the diets. Apparent total-tract digestibility of $\mathrm{EE}$ was lower for cows fed LF diets compared with HF diets (53.8 vs. $63.5 \%$; $P$ $<0.001$ ), whereas it was lower for cows fed 0DG diets than for those fed 18DG diets (55.4 vs. $61.9 \%$; $P=$ $0.02)$.

Forage $\times$ DDGS exhibited an interaction for digested EE $(P=0.003)$. Diet did not affect the amount of DM, $\mathrm{OM}, \mathrm{CP}, \mathrm{NDF}$, or ADF digested by cows. Cows fed LF $(6.25$ vs. $4.85 \mathrm{~kg} / \mathrm{d})$ and $0 D G \operatorname{diets}(6.12$ vs. $4.97 \mathrm{~kg} / \mathrm{d})$ digested a greater amount of starch compared with HF and 18DG diets, respectively.

\section{Lactation Performance}

Lactation performance of cows during the experiment is presented in Table 8 . No significant forage NDF $\times$ 
Table 7. Apparent total-tract digestibility of nutrients in dairy cows fed experimental diets ${ }^{1}$

\begin{tabular}{|c|c|c|c|c|c|c|c|c|}
\hline Item & \multicolumn{2}{|c|}{$\mathrm{LF}$} & \multicolumn{2}{|c|}{$\mathrm{HF}$} & SEM & \multicolumn{3}{|c|}{$P$-value ${ }^{2}$} \\
\hline \multicolumn{9}{|c|}{ Total-tract digestibility (\%) } \\
\hline $\mathrm{OM}$ & 74.9 & 71.9 & 71.7 & 70.9 & 1.60 & 0.21 & 0.25 & 0.49 \\
\hline $\mathrm{CP}$ & 73.0 & 71.0 & 71.3 & 72.0 & 1.61 & 0.83 & 0.70 & 0.42 \\
\hline NDF & 47.7 & 48.4 & 45.1 & 46.8 & 3.08 & 0.46 & 0.67 & 0.87 \\
\hline Ether extract & 51.9 & 55.7 & 58.9 & 68.0 & 2.08 & $<0.001$ & 0.02 & 0.25 \\
\hline \multicolumn{9}{|l|}{ Digested $(\mathrm{kg} / \mathrm{d})$} \\
\hline $\mathrm{DM}$ & 18.2 & 16.0 & 16.0 & 16.2 & 0.98 & 0.19 & 0.19 & 0.12 \\
\hline $\mathrm{OM}$ & 17.5 & 15.4 & 15.6 & 15.7 & 0.92 & 0.22 & 0.16 & 0.10 \\
\hline $\mathrm{CP}$ & $3.29^{\mathrm{a}}$ & $2.97^{\mathrm{a}}$ & $2.97^{\mathrm{a}}$ & $3.15^{\mathrm{a}}$ & 0.18 & 0.63 & 0.53 & 0.10 \\
\hline $\mathrm{NDF}$ & 2.97 & 3.19 & 3.05 & 3.60 & 0.27 & 0.33 & 0.15 & 0.50 \\
\hline $\mathrm{ADF}$ & 1.23 & 1.32 & 1.36 & 1.49 & 0.15 & 0.29 & 0.42 & 0.85 \\
\hline
\end{tabular}

${ }^{\mathrm{a}-\mathrm{c}}$ Treatment means in same row followed by different superscript letters differ significantly $(P<0.05)$.

${ }^{1}$ Diets provided varying concentrations of forage and distillers dried grains with solubles (DDGS); low forage (LF; $41 \%$ of diet DM) or high forage (HF; $60 \%$ of diet DM) and DDGS at 0 or $18 \%$ of diet DM. $0 \mathrm{DG}=0 \%$ DDGS; $18 \mathrm{DG}=18 \%$ DDGS.

${ }^{2} \mathrm{~F}=$ effect of dietary forage NDF concentration; DG = effect of DDGS concentration; $\mathrm{F} \times \mathrm{DG}=$ interaction of dietary forage NDF concentration and DDGS concentration $(P<0.05)$.

${ }^{3}$ PDIFF test was conducted if $P<0.05$ for interactions of main effects.

DDGS interactions were observed for any of the reported animal performance measures. Milk production, FCM, MUN, and feed efficiency were not affected by dietary treatments. Cows fed LF diets tended to have lower milk fat content (3.66 vs. $3.02 \% ; P=0.08)$ and a higher protein content (3.06 vs. $2.99 \% ; P=0.01$ ) than cows fed the HF diets. However, we found no dietary effect on fat or protein yield. Cows fed LF diets tended $(P=0.07)$ to have greater lactose concentration than cows fed LF diets, but there was no effect on lactose yield. Including DDGS in the diet did not affect milk production or components.

\section{DISCUSSION}

\section{Nutrient Intake}

Low-forage diets often result in greater DMI compared with HF diets (Kalscheur et al., 1997; Oba and Allen, 2000, 2003). However, as we observed in the cur-

Table 8 . Lactation performance by dairy cows fed experimental $\operatorname{diets}^{1}$

\begin{tabular}{|c|c|c|c|c|c|c|c|c|}
\hline Item & \multicolumn{2}{|c|}{$\mathrm{LF}$} & \multicolumn{2}{|c|}{$\mathrm{HF}$} & SEM & \multicolumn{3}{|c|}{$P$-value ${ }^{2}$} \\
\hline \multicolumn{9}{|l|}{ Production $(\mathrm{kg} / \mathrm{d})$} \\
\hline $\mathrm{ECM}^{3}$ & 33.1 & 29.5 & 34.5 & 35.2 & 4.84 & 0.27 & 0.64 & 0.49 \\
\hline \multicolumn{9}{|l|}{ Milk composition } \\
\hline Fat $(\%)$ & 3.01 & 3.02 & 3.50 & 3.81 & 0.36 & 0.08 & 0.62 & 0.62 \\
\hline Protein $(\mathrm{kg} / \mathrm{d})$ & 1.19 & 1.09 & 1.11 & 1.06 & 0.15 & 0.42 & 0.26 & 0.67 \\
\hline Lactose $(\%)$ & 4.88 & 4.84 & 4.77 & 4.68 & 0.11 & 0.07 & 0.30 & 0.69 \\
\hline Lactose $(\mathrm{kg} / \mathrm{d})$ & 1.89 & 1.77 & 1.79 & 1.68 & 0.28 & 0.44 & 0.34 & 0.94 \\
\hline MUN (mg/dL) & 12.4 & 13.0 & 12.0 & 12.7 & 0.63 & 0.42 & 0.22 & 0.93 \\
\hline Feed efficiency (ECM/DMI) & 1.45 & 1.41 & 1.58 & 1.53 & 0.16 & 0.32 & 0.69 & 0.99 \\
\hline
\end{tabular}

${ }^{1}$ Diets provided varying concentrations of forage and distillers dried grains with solubles (DDGS); low forage (LF; $41 \%$ of diet DM) or high forage (HF; $60 \%$ of diet DM) and DDGS at 0 or $18 \%$ of diet DM. $0 \mathrm{DG}=0 \%$ DDGS; $18 \mathrm{DG}=18 \%$ DDGS.

${ }^{2} \mathrm{~F}=$ effect of dietary forage NDF concentration; DG $=$ effect of DDGS concentration; $\mathrm{F} \times \mathrm{DG}=$ interaction of dietary forage NDF concentration and DDGS concentration $(P<0.05)$.

${ }^{3} \mathrm{ECM}=[0.327 \times$ milk yield $(\mathrm{kg})]+[12.95 \times$ fat yield $(\mathrm{kg})]+[7.2 \times$ protein yield $(\mathrm{kg})]$. 
rent study, the proportion of forage in the diets did not affect DMI of lactating dairy cows (Agle et al., 2010; Aguerre et al., 2011; Neveu et al., 2013). Allen (2000) suggested that DMI could be limited by the amount and digestibility of forage and the amount of propionate in the rumen rather than by the specific ratio of forage to concentrate in the diet. The current research contradicts this suggested hypothesis, because cows fed greater amounts of forage had less ruminal propionate and yet we did not observe a DMI response. Interestingly, our data agrees with other researchers who observed no response in DMI when including approximately $20 \%$ DDGS in lactating diets (Kleinschmit et al., 2006; Paz et al., 2013; Zanton et al., 2013). In contrast, other studies reported that feeding DDGS at approximately $20 \%$ of the diet (DM basis) increased (Kalscheur et al., 2012) or decreased (Ranathunga et al., 2010) DMI of lactating dairy cows.

\section{Rumen $\mathrm{pH}$ and Fermentation}

Our data support previous studies in which cows were fed HF diets to maintain greater ruminal $\mathrm{pH}$ with (Benchaar et al., 2013) or without (Kalscheur et al., 1997; Oba and Allen, 2000, 2003) DDGS in the diet. This indicated that diets with high forage concentration maintain greater ruminal $\mathrm{pH}$ with the help of increased chewing and salivation, and greater ruminal buffering capacity, attributed to greater effective fiber concentration. On the contrary, as we observed in our study, low-forage diets with (Ramirez-Ramirez et al., 2012, 2016) or without DDGS (Kalscheur et al., 1997; Oba and Allen, 2000, 2003) could lower the ruminal $\mathrm{pH}$. Interactions between forage and DDGS concentrations observed in our study for the daily mean $\mathrm{pH}$ were attributed to the lowest daily mean $\mathrm{pH}$ observed with cows fed LF18DG diet. Cumulative effects of ruminal degradation of a higher starch content (25\%) and $18 \%$ DDGS may have resulted in the lowest ruminal $\mathrm{pH}$ for cows fed LF18DG diet. Also, the acidic nature of DDGS (US Grains Council, 2012), attributed to the presence of lactic acid in DDGS (Fron et al., 1996; Kim et al., 2008) or to the addition of sulfuric acid during the dry-grind ethanol production process (US Grains Council, 2012), may have an effect on lowering ruminal $\mathrm{pH}$ in the cows fed LF18DG diet.

Effects of forage on total VFA concentration are well documented. Low-forage diets fed with a greater concentration of fermentable carbohydrates yield greater total VFA concentrations, as we observed in our study (Kalscheur et al., 1997; Agle et al., 2010). Contrary to that, Oba and Allen (2003) observed that VFA concentration was not affected by forage level. However, they noted that LF diets had greater amounts of truly fermented OM compared with HF diets, and they found no relationship between total VFA concentration and true ruminally degraded OM. Total VFA concentration responses to feeding DDGS have been inconsistent. As we observed in our study, Zhang et al. (2010) reported no effect of DDGS on total VFA concentration when DDGS was fed at $20 \%$ with low or high forage concentrations. Contrary to our observation, Benchaar et al. (2013) demonstrated a negative effect of DDGS on total VFA production. When they fed increasing levels of DDGS from 0 to $30 \%$ of DM, with $60 \%$ forage concentration, there was a linear decrease of total VFA concentration from 99.3 to $91.1 \mathrm{mM}$. In another study, Ramirez-Ramirez et al. (2012) demonstrated the greatest total VFA concentration $(130 \mathrm{mM})$ when DDGS was fed at $30 \%$ of DM with $41 \%$ of brown midrib corn silage. This could have been attributable to highly digestible fiber from brown midrib corn and DDGS.

Low-forage diets decrease molar proportions of acetate, increase molar proportions of propionate, and lower the ratio of acetate to propionate (Oba and $\mathrm{Al}-$ len, 2000, 2003; Neveu et al., 2013). Lower acetate and higher propionate molar proportions in LF diets are mostly attributable to starch degradation and its negative effect on fiber digestion. Contrary to our observation, Kalscheur et al. (1997) reported a greater molar proportion of butyrate for LF diets. Other studies have reported no effect of forage concentration on molar proportion of butyrate, whereas its effect on molar proportion on branched VFA is variable (Oba, Allen, 2000, 2003; Neveu et al., 2013).

Previous studies have demonstrated that feeding corn DDGS to lactating dairy cows at $\geq 20 \%$ DM can decrease acetate molar proportion and increase propionate molar proportion in the rumen, irrespective of low (Ramirez-Ramirez et al., 2016) or high (Ramirez-Ramirez et al., 2012; Benchaar et al., 2013) forage concentration in the diet. However, in our study, feeding both LF and 18DG diets decreased the acetate molar proportion and increased the propionate molar proportion. Benchaar et al. (2013) suggested that an increase in propionate molar proportion as dietary proportion of DDGS increases is a consequence of a decline in acetate molar proportion rather than an increase in propionate concentration. However, in the current study, cows fed LF18DG demonstrated a greater ruminal propionate concentration $(34.5 \mathrm{mM})$ compared with cows fed other diets, without affecting ruminal acetate concentration (data not shown). Decreased isovalerate molar proportions with feeding DGGS was consistent with other studies (Anderson et al., 2006; Kelzer et al., 2009; Benchaar et al., 2013). The decreased branched 
short-chain fatty acids possibly reflected the relatively low content of branched-chain AA in diets high in corn products (Schingoethe et al., 1999). Benchaar et al. (2013) indicated that decreased molar proportion of branched-chain VFA and ruminal $\mathrm{NH}_{3}$ concentration attributed to feeding DDGS was an indication of reduction of ruminal degradation of protein.

\section{Rumen Fill and Ruminal Digestion Kinetics}

Nutrient intake, nutrient pools, and passage rate together may explain how nutrients degraded under different ruminal conditions. The effect of dietary forage concentration on ruminal wet content is variable. A few studies agreed with our data, in which there were more wet content in the rumen when cows were fed HF diets (Voelker et al., 2002; Suarez-Mena et al., 2013); however, other studies reported no effect of forage concentration on ruminal wet content (Yang et al., 2001a; Penner et al., 2009). Greater moisture content and $\mathrm{WHC}$ of $\mathrm{HF}$ diets, accompanied by increased saliva secretion, may be attributed to greater ruminal wet content and liquid pool compared with LF diets.

Consistent with previous studies, we observed slower passage rates for cows fed LF diets compared with HF diets (Colucci et al., 1990; Huhtanen and Jaakkola, 1993) and no dietary effects on fractional dilution rates (Krämer et al., 2013). Ruminal fermentation of starch with highly digestible non-forage NDF from DDGS could rapidly decrease ruminal $\mathrm{pH}$, thus suppressing fiber-digesting microflora. Fibrolytic bacteria are sensitive to ruminal $\mathrm{pH}$, and when ruminal $\mathrm{pH}$ decreases below a critical value, rumen fiber digestion decreases rapidly. Fiber digestion is impaired when ruminal $\mathrm{pH}$ drops below approximately 6.0 to 6.3 (Erdman, 1988; Mouriño et al., 2001). In addition, a greater unsaturated FA load from DDGS (Schingoethe et al., 2009) may overwhelm the rumen environment and the antibacterial action of polyunsaturated FA (Chalupa et al., 1984), which could also reduce the fiber-digesting bacteria population. This could decrease fiber digestibility and leave undigested fiber fractions in the rumen for a longer time. Also, the lack of "scratch factor" attributed to lower forage NDF intake may disturb rumination and mastication, thus decreasing saliva flow to affect the buffering capacity of the rumen (Dijkstra et al., 2012).

Feeding DDGS with HF concentrations may affect ruminal nutrient degradability differently than DDGS fed with LF concentrations. Greater intake of total $\mathrm{NDF}$, forage NDF, ADF, and EE, and higher solid passage rates in the rumen may indicate lower degradability of particular nutrients in the rumen. However, in situ degradability data from our companion study revealed that the HF18DG diet had the greatest NDF and ADF effective degradabilites (Ranathunga et al., 2011). Also, greater milk fat concentration from cows fed HF18DG diet indicated that greater unsaturated fatty acid concentration from the DDGS diet did not negatively affect biohydrogenation of the unsaturated fatty acids, and there was lower negative effect on fiber degradability in the rumen. High-forage diets form a thick rumen mat, which scratches the rumen wall to stimulate the rumination process. This process leads to increased mastication and salivation and higher ruminal pH. Increased mastication breaks down longer fiber particles and allows greater degradability and faster passage from the rumen (Dijkstra et al., 2012). A faster passage rate of solid phase means that fiber particles stay in the rumen for a shorter time. However, improved fiber degradability indicated greater microbial activity on fiber digestion. Grant (1997) suggested that the thick rumen mat attributed to HF diets may retain non-forage particles to slow down passage from the rumen, as non-forage particles are characterized by smaller particle size and greater specific gravity than forage particles. The smaller average particle size $(0.46-1.18$ $\mathrm{mm}$; Kleinschmit et al., 2007) and greater specific gravity (1.24; Bhatti and Firkins, 1995) of DDGS suggest that DDGS would stay longer in the rumen with HF diets. However, fractional passage rates estimated using Er-labeled DDGS indicated that DDGS stayed in the rumen for a similar amount of time across the diets. In situ degradability data from our companion study demonstrated that DDGS had greater NDF and ADF effective degradabilities when DDGS was fed with HF concentrations (Ranathunga et al., 2011). This could be attributed to the presence of more fiber-digesting bacteria, owing to more favorable rumen conditions such as higher ruminal $\mathrm{pH}$.

\section{Apparent Total-Tract Digestibility}

Apparent total-tract digestibility data demonstrated that when they were fed 4 different diets, cows depended on different sources of nutrients to obtain their nutritional requirements. For example, starch digested as a portion of DM was greatest for cows fed LFODG at $38 \%$, whereas it was 35,33 , and $27 \%$ for LF $18 D G$, HF0DG, and HF18DG diets, respectively. Lower totaltract digestibilities for fiber were reported for cows fed LF diets, possibly attributable to unfavorable ruminal conditions for fiber-digesting microorganisms, such as lower ruminal pH (Kalscheur et al., 1997; Yang et al., 2001b). However, our data indicated no dietary effect on total-tract digestibility for NDF and ADF. Lower 
NDF intake and greater ruminal retention time may have allowed cows fed the LFODG diet to digest fiber even though lower ruminal $\mathrm{pH}$ was unfavorable for fiber-digesting microorganisms compared with cows fed HF diets. However, cows fed HF18DG digested numerically greater amounts of NDF and ADF (NDF and ADF kg digested per d) compared with cows fed the other diets. This could be possibly attributed to higher ruminal $\mathrm{pH}$, which favors fiber-digesting microorganisms. Also, greater digestibility of EE contributed a significant portion of required energy for cows fed HF and 18DG diets compared with cows fed LF and 0DG diets, respectively. The HF18DG diet exhibited the greatest amount of EE digested ( $\mathrm{kg}$ digested per d), indicating that HF dietary conditions were conducive to digestibility of the unsaturated fatty acid load from DDGS. Because rumen microorganisms perform extensive metabolism of lipids, existing ruminal conditions such as ruminal $\mathrm{pH}$ may have affected the variation in the digestibility and amount of digested EE (Harfoot and Hazlewood, 1997). Lower ruminal $\mathrm{pH}$ observed in cows fed LF diets may have negatively affected the extent of lipid hydrolysis (Van Nevel and Demeyer, 1996a, b; Harfoot and Hazlewood, 1997), thus decreasing the total-tract digestibility of EE. The reason for improved EE digestibility among cows fed 18DG compared with ODG diets is not known.

\section{Lactation Performance}

We observed higher SEM values for milk production and milk component data in the current study than in our parallel production study with 12 lactating cows in mid lactation with an initial DIM of $107 \pm 17$ (Ranathunga et al., 2018). We conducted the production study during the same time frame as the current study and used the same experimental design and same diets to feed cows. However, none of the statistical interpretations of dietary effect on milk production and milk components in the current study were different compared with the other study.

Low-forage and high-concentrate diets often result in greater milk yield (Oba and Allen, 2000, 2003; Voelker Linton and Allen, 2007). In our study, we observed no dietary effect on milk and energy-corrected milk, indicating that all cows spent similar amounts of energy to produce milk. Inclusion of DDGS in lactating dairy cow diets has variable effects on milk yield. Meta-analyses of previous studies on feeding distillers grains (both wet and dried) to lactating cows and reviews of distillers grains indicated that cows fed diets containing distillers grains produced either similar or improved amounts of milk compared with cows fed control diets with $0 \%$ distillers grains (Schingoethe et al., 2009; Hollmann et al., 2011; Kalscheur et al., 2012; Paz et al., 2013), as we observed in our study. Also, our present data support our previous data on partial replacement of ground corn and soybean feeds with DDGS, demonstrating that diets formulated with DDGS were able to sustain milk production compared with a control diet including 0\% DDGS (Ranathunga et al., 2010).

Feeding diets with LF with the higher unsaturated fat from the DDGS is thought to cause MFD. In the current study, milk fat concentration and yield for cows fed LF diets decreased by 17.5 and $19.6 \%$, respectively, compared with cows fed HF diets. This agrees with previously reported associations of MFD with LF diets (Griinari et al., 1998; Peterson et al., 2003; Rico and Harvatine, 2013). Our data demonstrated that adequate physically effective fiber is necessary to maintain higher ruminal $\mathrm{pH}$. Limited fiber degradation in LF diets may limit precursors for fat synthesis, such as acetate and butyrate. Also, incomplete biohydrogenation of polyunsaturated fatty acid in the rumen may inhibit de novo fatty acid synthesis (Bauman and Griinari, 2001). Another study demonstrated that elevated ruminal propionate concentration associated with LF diets may have a role in MFD (Maxin et al., 2011). Contrary to LF diets, HF diets maintain normal rumen conditions and ferment the fiber fraction to precursors of acetate and butyrate. Also, increased milk fat concentration, along with numerically high milk fat yield, indicated increased biohydrogenation of unsaturated FA when DDGS was fed with HF diets, and this combination exhibited no negative effect on de novo FA synthesis.

\section{CONCLUSIONS}

This study demonstrated that forage and DDGS inclusion affected the chemical characteristics of diets and nutrient availability in the rumen. Cows fed LF diets exhibited lower ruminal $\mathrm{pH}$, which we attribute to greater ruminal degradation of rapidly degrading carbohydrates. Under such ruminal conditions, fiber digestion for cows fed LF diets may have negatively affected the fiber fraction so that it was retained in the rumen for a longer time. By contrast, cows fed HF diets may have maintained a higher ruminal $\mathrm{pH}$ and increased ruminal fiber digestion. Greater solid passage rates for $\mathrm{HF}$ diets indicated that fiber was retained in the rumen for a shorter period. However, total-tract digestibility of the nutrients was not affected by diet, except for EE. These results demonstrated that providing forage NDF at $17 \%$ on a DM basis can decrease milk fat concentration, whereas providing forage NDF at $25 \%$ DM basis can sustain milk fat concentration. Additionally, feed- 
ing DDGS at $18 \%$ DM basis to lactating dairy cows did not affect milk fat concentration or yield when included at either forage NDF concentration.

\section{ACKNOWLEDGMENTS}

The authors express appreciation to Matthew Laubach, Stephen Crego, Pete Linke, and other personnel at the South Dakota State University Dairy Teaching and Research Facility (Brookings), for the feeding and care of animals in this study, and to Heidi Bruns (South Dakota State University, Brookings), Kamal Mjoun (Alltech, Brookings, SD), David Casper (Furst-McNess Company, Freeport, IL), and Jeff Horst (Agri-King Inc., Fulton, IL) for assistance in sample collection and analysis. This work was supported in part by the South Dakota Agricultural Experiment Station (Brookings) and USDA-ARS Agreement No. 58-5447-7-322 and was a component of NC-1042: Management Systems to Improve the Economic and Environmental Sustainability of Dairy Enterprises. Mention of any trademark or proprietary product in this paper does not constitute a guarantee or endorsement of the product by the USDA or the Agricultural Research Service and does not imply its approval to the exclusion of other products that also may be suitable.

\section{REFERENCES}

Abdelqader, M. M., A. R. Hippen, K. F. Kalscheur, D. J. Schingoethe, and A. D. Garcia. 2009. Isolipidic additions of fat from corn germ, corn distillers grains, or corn oil in dairy cow diets. J. Dairy Sci. 92:5523-5533. https://doi.org/10.3168/jds.2008-1867.

Agle, M., A. N. Hristov, S. Zaman, C. Schneider, P. M. Ndegwa, and V. K. Vaddella. 2010. Effect of dietary concentrate on rumen fermentation, digestibility, and nitrogen losses in dairy cows. J. Dairy Sci. 93:4211-4222. https://doi.org/10.3168/jds.2009-2977.

Aguerre, M. J., M. A. Wattiaux, J. M. Powell, G. A. Broderick, and C. Arndt. 2011. Effect of forage-to-concentrate ratio in dairy cow diets on emission of methane, carbon dioxide, and ammonia, lactation performance, and manure excretion. J. Dairy Sci. 94:30813093. https://doi.org/10.3168/jds.2010-4011.

Allen, M. S. 2000. Effects of diet on short-term regulation of feed intake by lactating dairy cattle. J. Dairy Sci. 83:1598-1624. https:// doi.org/10.3168/jds.S0022-0302(00)75030-2.

Anderson, J. L., D. J. Schingoethe, K. F. Kalscheur, and A. R. Hippen. 2006. Evaluation of dried and wet distillers grains included at two concentrations in the diets of lactating dairy cows. J. Dairy Sci. 89:3133-3142. https://doi.org/10.3168/jds.S0022-0302(06)72587 $-5$.

AOAC International. 2002. Official Methods of Analysis. 17th ed. AOAC Int., Gaithersburg, MD.

AOAC International. 2006. Official Methods of Analysis. 18th ed. AOAC Int., Gaithersburg, MD.

ASAE. 2001. S424: Method of determining and expressing particle size of chopped forage materials by sieving. In Standards Am. Soc. Agric. Eng., St. Joseph, MI.

Bauman, D. E., and J. M. Griinari. 2001. Regulation and nutritional manipulation of milk fat: Low-fat milk syndrome. Livest. Prod. Sci. 70:15-29. https://doi.org/10.1016/S0301-6226(01)00195-6.
Benchaar, C., F. Hassanat, R. Gervais, P. Y. Chouinard, C. Julien, H. V. Petit, and D. I. Massé. 2013. Effects of increasing amounts of corn dried distillers grains with solubles in dairy cow diets on methane production, ruminal fermentation, digestion, $\mathrm{N}$ balance, and milk production. J. Dairy Sci. 96:2413-2427. https://doi.org/ 10.3168/jds.2012-6037.

Bhatti, S. A., and J. L. Firkins. 1995. Kinetics of hydration and functional specific gravity of fibrous feed by-products. J. Anim. Sci. 73:1449-1458.

Chalupa, W., B. Rickabaugh, D. S. Kronfeld, and D. Sklan. 1984. Rumen fermentation in vitro as influenced by long chain fatty acids. J. Dairy Sci. 67:1439-1444. https://doi.org/10.3168/jds.S0022 -0302(84)81459-9.

Chaney, A. L., and E. P. Marbach. 1962. Modified reagents for determination of urea and ammonia. Clin. Chem. 8:130-132.

Colucci, P. E., G. K. Macleod, W. L. Grovum, I. McMillan, and D. J. Barney. 1990. Digesta kinetics in sheep and cattle fed diets with different forage to concentrate ratios at high and low intakes. J. Dairy Sci. 73:2143-2156. https://doi.org/10.3168/jds.S0022 -0302(90)78895-9.

Dijkstra, J., J. L. Ellis, E. Kebreab, A. B. Strathe, S. López, J. France, and A. Bannink. 2012. Ruminal pH regulation and nutritional consequences of low pH. Anim. Feed Sci. Technol. 172:22-33. https:// doi.org/10.1016/j.anifeedsci.2011.12.005.

Ellis, W. C., and D. E. Beever. 1984. Methods for binding rare earths to specific feed particles. Pages 154-165 in Techniques in Particle Size Analysis of Feed and Digesta in Ruminants. P.M. Kennedy, ed. Canadian Society of Animal Science, Occasional Publication No. 1, Edmonton, Alberta, Canada.

Erdman, R. A. 1988. Dietary buffering requirements of the lactating dairy cow: A review. J. Dairy Sci. 71:3246-3266. https://doi.org/ 10.1016/j.anifeedsci.2011.12.005.

Fron, M., H. Madeira, C. Richards, and M. Morrison. 1996. The impact of feeding condensed distillers byproducts on rumen microbiology and metabolism. Anim. Feed Sci. Technol. 61:235-245. https://doi.org/10.1016/0377-8401(95)00943-4.

Grant, R. J. 1997. Interaction among forages and nonforage fiber sources. J. Dairy Sci. 80:1438-1446. https://doi.org/10.3168/jds .S0022-0302(97)76073-9.

Griinari, J. M., D. A. Dwyer, M. A. McGuire, D. E. Bauman, D. L. Palmquist, and K. V. V. Nurmela. 1998. Trans-octadecenoic acids and MFD in lactating dairy cows. J. Dairy Sci. 81:1251-1261. https://doi.org/10.3168/jds.S0022-0302(98)75686-3.

Grovum, W. L., and V. J. Williams. 1973. Rate of passage of digesta in sheep. 3. Differential rates of passage of water and dry matter from the reticulo-rumen, abomasum and caecum and proximal colon. Br. J. Nutr. 30:231-240. https://doi.org/10.1079/BJN19730029.

Harfoot, C. G., and G. P. Hazlewood. 1997. Lipid metabolism in the rumen. Pages 382-426 in The Rumen Microbial Ecosystem. P. N. Hobson and C. S. Stewart, ed. Chapman \& Hall, London, UK.

Herrick, K. J., A. R. Hippen, K. F. Kalscheur, J. L. Anderson, S. D. Ranathunga, R. S. Patton, and M. Abdullah. 2012. Lactation performance and digestibility of forages and diets in dairy cows fed a hemicellulose extract. J. Dairy Sci. 95:3342-3353. https://doi.org/ 10.3168/jds.2011-5168.

Hippen, A. R., D. J. Schingoethe, K. F. Kalscheur, P. L. Linke, D. R. Rennich, M. M. Abdelqader, and I. Yoon. 2010. Saccharomyces cerevisiae fermentation product in dairy cow diets containing dried distillers grains plus solubles. J. Dairy Sci. 93:2661-2669. https:// doi.org/10.3168/jds.2009-3040.

Hollmann, M., M. S. Allen, and D. K. Beede. 2011. Diet fermentability influences lactational performance responses to corn distillers grains: A meta-analysis. J. Dairy Sci. 94:2007-2021. https://doi .org/10.3168/jds.2010-3711.

Huhtanen, P., and S. Jaakkola. 1993. The effects of forage preservation method and proportion of concentrate on digestion of cell-wall carbohydrates and rumen digesta pool size in cattle. Grass Forage Sci. 48:155-165. https://doi.org/10.1111/j.1365-2494.1993.tb01848.x.

Kalscheur, K. F., A. D. Garcia, D. J. Schingoethe, F. Diaz Royón, and A. R. Hippen. 2012. Feeding biofuel co-products to dairy cattle. 
Pages 115-153 in Biofuel Co-Products as Livestock Feed-Opportunities and Challenges. H. P. S. Makkar, ed. FAO, Rome, Italy.

Kalscheur, K. F., B. B. Teter, L. S. Piperova, and R. A. Erdman. 1997. Effect of dietary forage concentration and buffer addition on duodenal flow of trans-C18:1 fatty acids and milk fat production in dairy cows. J. Dairy Sci. 80:2104-2114. https://doi.org/10.3168/ jds.S0022-0302(97)76156-3.

Karimi, A. R., F. N. Owens, and G. W. Horn. 1986. Simultaneous extraction of $\mathrm{Yb}$, Dy and Co from feces with DCTA, DTPA or EDTA. Pages 118-126 in Okla. Agric. Exp. Sta. MP-119.

Kelzer, J. M., P. J. Kononoff, A. M. Gehman, L. O. Tedeschi, K. Karges, and M. L. Gibson. 2009. Effects of feeding three types of corn-milling coproducts on milk production and ruminal fermentation of lactating Holstein cattle. J. Dairy Sci. 92:5120-5132. https: //doi.org/10.3168/jds.2009-2208.

Kim, Y., N. S. Mosier, R. Hendrickson, T. Ezeji, H. Blaschek, B. Dien, M. Cotta, B. Dale, and M. R. Ladisch. 2008. Composition of corn dry-grind ethanol by-products: DDGS, wet cake, and thin stillage. Bioresour. Technol. 99:5165-5176. https://doi.org/10.1016/j .biortech.2007.09.028.

Kleinschmit, D. H., J. L. Anderson, D. J. Schingoethe, K. F. Kalscheur, and A. R. Hippen. 2007. Ruminal and intestinal digestibility of distillers grains plus solubles varies by source. J. Dairy Sci. 90:2909-2918. https://doi.org/10.3168/jds.2006-613.

Kleinschmit, D. H., D. J. Schingoethe, K. F. Kalscheur, and A. R. Hippen. 2006. Evaluation of various sources of corn dried distillers grains plus solubles for lactating dairy cattle. J. Dairy Sci. 89:4784-4794. https://doi.org/10.3168/jds.S0022-0302(06)72528 -0 .

Krämer, M., P. Lund, and M. R. Weisbjerg. 2013. Rumen passage kinetics of forage- and concentrate-derived fiber in dairy cows. J. Dairy Sci. 96:3163-3176. https://doi.org/10.3168/jds.2012-6146.

Littell, R. C., G. A. Milliken, W. W. Stroup, and R. D. Wolfinger. 1996. SAS system for mixed models. SAS Institute, Cary, NC.

Lock, A. L. 2010. Update on dietary and management effects on milk fat. Pages 15-26 in Proc. Tri-State Dairy Nutr. Conf., Fort Wayne, IN. The Ohio State University Extension, Columbus.

Maxin, G.. F. Glasser, C. Hurtaud, J. L. Peyraud, and H. Rulquin. 2011. Combined effects of trans-10, cis-12 conjugated linoleic acid, propionate, and acetate on milk fat yield and composition in dairy cows. J. Dairy Sci. 94:2051-2059. https://doi.org/10.3168/jds.2010 -3844 .

Mertens, D. R. 1997. Creating a system for meeting the fiber requirements of dairy cows. J. Dairy Sci. 80:1463-1481. https://doi.org/ 10.3168/jds.S0022-0302(97)76075-2.

Mouriño, F., R. A. Akkarawongsa, and P. J. Weimer. 2001. Initial $\mathrm{pH}$ as a determinant of cellulose digestion rate by mixed ruminal microorganisms in vitro. J. Dairy Sci. 84:848-859. https://doi.org/ 10.3168/jds.S0022-0302(01)74543-2.

Myers, W. D., P. A. Ludden, V. Nayigihugu, and B. W. Hess. 2004. Technical note: A procedure for the preparation and quantitative analysis of samples for titanium dioxide. J. Anim. Sci. 82:179-183. https://doi.org/10.3168/jds.S0022-0302(01)74543-2.

Neveu, C., B. Baurhoo, and A. Mustafa. 2013. Effect of feeding extruded flaxseed with different forage:concentrate ratios on the performance of dairy cows. J. Dairy Sci. 96:3886-3894. https://doi .org/10.3168/jds.2012-6189.

NRC (National Research Council). 2001. Nutrient Requirements of Dairy Cattle. 7th rev. ed. Natl. Acad. Press, Washington, DC.

Oba, M., and M. S. Allen. 2000. Effects of brown midrib 3 mutation in corn silage on productivity of dairy cows fed two concentrations of dietary neutral detergent fiber: 1 . Feeding behavior and nutrient utilization. J. Dairy Sci. 83:1333-1341. https://doi.org/10.3168/ jds.S0022-0302(00)75000-4.

Oba, M., and M. S. Allen. 2003. Effects of corn grain conservation method on feeding behavior and productivity of lactating dairy cows at two dietary starch concentrations. J. Dairy Sci. 86:174183. https://doi.org/10.3168/jds.S0022-0302(03)73598-X.

Orth, R. 1992. Sample Day and Lactation Report. DHIA 200 Fact Sheet A-2. Mid-states DRPC, Ames, IA.
Owen, F. G., and L. L. Larson. 1991. Corn distillers dried grains versus soybean meal in lactation diets. J. Dairy Sci. 74:972-979. https:// doi.org/10.3168/jds.S0022-0302(91)78246-5.

Paz, H. A., E. Castillo-Lopez, H. A. Ramirez-Ramirez, D. A. Christensen, T. J. Klopfenstein, and P. J. Kononoff. 2013. Invited Review: Ethanol co-products for dairy cows: There goes our starch

Now what? Can. J. Anim. Sci. 93:407-425. https://doi.org/10 .1139/CJAS2013-048.

Penner, G. B., M. Taniguchi, L. L. Guan, K. A. Beauchemin, and M. Oba. 2009. Effect of dietary forage to concentrate ratio on volatile fatty acid absorption and the expression of genes related to volatile fatty acid absorption and metabolism in ruminal tissue. J. Dairy Sci. 92:2767-2781. https://doi.org/10.3168/jds.2008-1716.

Peterson, D. G., E. A. Matitashvili, and D. E. Bauman. 2003. Dietinduced MFD in dairy cows results in increased trans-10, cis-12 CLA in milk fat and coordinate suppression of mRNA abundance for mammary enzymes involved in milk fat synthesis. J. Nutr. 133:3098-3102.

Powers, W. J., H. H. Van Horn, B. Harris Jr., and C. J. Wilcox. 1995. Effects of variable sources of distillers dried grains plus solubles on milk yield and composition. J. Dairy Sci. 78:388-396. https://doi .org/10.3168/jds.S0022-0302(95)76647-4.

Ramirez-Ramirez, H. A., E. Castillo Lopez, C. J. R. Jenkins, N. D. Aluthge, C. Anderson, S. C. Fernando, K. J. Harvatine, and P. J. Kononoff. 2016. Reduced-fat dried distillers grains with solubles reduces the risk for MFD and supports milk production and ruminal fermentation in dairy cows. J. Dairy Sci. 99:1912-1928. https: //doi.org/10.3168/jds.2015-9712.

Ramirez-Ramirez, H. A., K. Nestor, L. O. Tedeschi, T. R. Callaway, S. E. Dowd, S. C. Fernando, and P. J. Kononoff. 2012. The effect of brown midrib corn silage and dried distillers' grains with solubles on milk production, nitrogen utilization and microbial community structure in dairy cows. Can. J. Anim. Sci. 92:365-380. https://doi .org/10.4141/cjas2011-133.

Ranathunga, S. D., K. F. Kalscheur, A. R. Hippen, and D. J. Schingoethe. 2010. Replacement of starch from corn with non-forage fiber from distillers grains and soyhulls in diets of lactating dairy cows. J. Dairy Sci. 93:1086-1097. https://doi.org/10.3168/jds.2009 -2332 .

Ranathunga, S. D., K. F. Kalscheur, A. R. Hippen, and D. J. Schingoethe. 2011. In situ ruminal degradability of diets, dried distillers grains with solubles and soybean meal under different rumen conditions. J. Dairy Sci. 94 (E-Suppl. 1):65. (Abstr.)

Ranathunga, S. D., K. F. Kalscheur, J. L. Anderson, and K. J. Herrick. 2018. Production of dairy cows fed distillers dried grains with solubles in low- and high-forage diets. J. Dairy Sci. 101:1088610898. https://doi.org/10.3168/jds.2017-14258.

Rico, D. E., and K. J. Harvatine. 2013. Induction of and recovery from MFD occurs progressively in dairy cows switched between diets that differ in fiber and oil concentration. J. Dairy Sci. 96:66216630. https://doi.org/10.3168/jds.2013-6820.

Robertson, J. A., M. A. Eastwood, and M. M. Yeoman. 1980. An investigation into the physical properties of fibre prepared from several carrot varieties at different stages of development. J. Sci. Food Agric. 31:633-638. https://doi.org/10.1002/jsfa.2740310703.

Robertson, J. B., and P. J. Van Soest. 1981. The detergent system of analysis and its application to human foods. Pages 123-158 in The Analysis of Dietary Fiber in Food. W. P. T. James and O. Theander, ed. Marcel Dekker Inc., New York, NY.

Schingoethe, D. J., M. J. Brouk, and C. P. Birkelo. 1999. Milk production and composition from cows fed wet corn distillers grains. J. Dairy Sci. 82:574-580. https://doi.org/10.3168/jds.S0022 -0302(99)75269-0.

Schingoethe, D. J., K. F. Kalscheur, A. R. Hippen, and A. D. Garcia. 2009. Invited review: The use of distillers products in dairy cattle diets. J. Dairy Sci. 92:5802-5813. https://doi.org/10.3168/ jds.2009-2549.

Shreve, B., N. Thiex, and M. Wolf. 2006. NFTA Method 2.1.4-Dry Matter by Oven Drying for 3 Hours at $105^{\circ} \mathrm{C}$. NFTA Reference Methods. National Forage Testing Association, Omaha, NE. 
Suarez-Mena, F. X., G. J. Lascano, and A. J. Heinrichs. 2013. Chewing activities and particle size of rumen digesta and feces of precision-fed dairy heifers fed different forage levels with increasing levels of distillers grains. J. Dairy Sci. 96:5184-5193. https://doi .org/10.3168/jds.2012-6155.

Testroet, E. D., D. C. Beitz, M. R. O'Neil, A. L. Mueller, H. A Ramirez-Ramirez, and S. Clark. 2018. Feeding reduced-fat dried distillers grains with solubles to lactating Holstein dairy cows does not alter milk composition or cause late blowing in cheese. J. Dairy Sci. 101:5838-5850. https://doi.org/10.3168/jds.2017-13699.

Udén, P., P. E. Colucci, and P. J. Van Soest. 1980. Investigation of chromium, cerium and cobalt as markers in digesta. Rate of passage studies. J. Sci. Food Agric. 31:625-632. https://doi.org/10 $.1002 /$ jsfa. 2740310702 .

U.S. Grains Council. 2012. A guide to distillers dried grains with solubles (DDGS). 3rd ed. Accessed Sep. 28, 2017. http://www.grains .org/sites/default/files/ddgs-handbook/Complete\%202012\%20 DDGS\%20Handbook.pdf.

Van Nevel, C. J., and D. I. Demeyer. 1996a. Effect of pH on biohydrogenation of polyunsaturated fatty acids and their Ca-salts by microorganisms in vitro. Arch Tierernahr. 49:151-157.

Van Nevel, C. J., and D. I. Demeyer. 1996b. Influence of pH on lipolysis and biohydrogenation of soybean oil by rumen contents in vitro. Reprod. Nutr. Dev. 36:53-63.

Van Soest, P. J., J. B. Robertson, and B. A. Lewis. 1991. Methods for dietary fiber, neutral detergent fiber, and non-starch polysaccharides in relation to animal nutrition. J. Dairy Sci. 74:3583-3597. https://doi.org/10.3168/jds.S0022-0302(91)78551-2.

Varga, G. A., and E. C. Prigge. 1982. Influence of forage species and level of intake on ruminal turnover rates. J. Anim. Sci. 55:1498 1504 .
Voelker, J. A., G. M. Burato, and M. S. Allen. 2002. Effects of pretrial milk yield on responses of feed intake, digestion, and production to dietary forage concentration. J. Dairy Sci. 85:2650-2661. https:// doi.org/10.3168/jds.S0022-0302(02)74350-6.

Voelker Linton, J. A., and M. S. Allen. 2007. Nutrient demand affects ruminal digestion responses to a change in dietary forage concentration. J. Dairy Sci. 90:4770-4779. https://doi.org/10.3168/jds .2007-0100.

Yang, W. Z., K. A. Beauchemin, and L. M. Rode. 2001a. Barley processing, forage:concentrate, and forage length effects on chewing and digesta passage in lactating cows. J. Dairy Sci. 84:2709-2720. https://doi.org/10.3168/jds.S0022-0302(01)74725-X.

Yang, W. Z. K. A. Beauchemin, and L. M. Rode. 2001b. Effects of grain processing, forage to concentrate ratio, and forage particle size on rumen $\mathrm{pH}$ and digestion by dairy cows. J. Dairy Sci. 84:2203-2216. https://doi.org/10.3168/jds.S0022-0302(01)74667 $-\mathrm{X}$.

Zanton, G. I., J. Heinrichs, and C. M. Jones. 2013. Short communication: Effects of level of rumen-degradable protein and corn distillers grains in corn silage-based diets on milk production and ruminal fermentation in lactating dairy cows. J. Dairy Sci. 96:4638-4642. https://doi.org/10.3168/jds.2012-6030.

Zhang, S. Z., G. B. Penner, W. Z. Yang, and M. Oba. 2010. Effects of partially replacing barley silage or barley grain with dried distillers grains with solubles on rumen fermentation and milk production of lactating dairy cows. J. Dairy Sci. 93:3231-3242. https://doi.org/ 10.3168/jds.2009-3005 